\title{
THE ISOLATION OF THE GONOCOCCUS AND ITS DIFFERENTIATION FROM ALLIED ORGANISMS. ${ }^{1}$
}

\author{
By W. Blatr M. Martin, M.B., Ch.B., Carnegie Rescarch Fellow. \\ From the Pathological Laboratory of Glasgow University and Glasgow Western Infirmary.
}

(Plates XV.-XVIII.).

ISOI,ATION.

Since E. Bumm (1885) first succeeded in cultivating the gonococcus on solidified human placental serum many attempts have been made to facilitate the isolation of this organism. The number of special media which have from time to time been devised for this purpose is of itself an indication of the difficulties surrounding the subject. The great variety in the composition of these media, ${ }^{2}$ coupled with the common experience that a medium successful in one person's hands has not been equally so in others, suggests that either individual strains of gonococci vary much in their adaptability to a vegetative existence, or that some important factor is commonly overlooked in the compounding of culture media. Both suppositions are indeed true.

The dictum of Neisser in 1899 regarding growths on ordinary agar, that "Alles was wächst, sind sicher keine Gonokokken," must go. The true nature of the organisms isolated on ordinary media by some of the early workers may be in doubt, but Thalmann (1900) undoubtedly obtained primary cultures - sub-cultures failed-on his agar. Again, Wildbolz (1902) succeeded in maintaining growth on agar after several sub-cultures on serum agar, but Vannod (1905) both isolated and naintained a number of strains on plain agar, and I have been able to confirm his results. Vannod, however, does not claim his agar to be the best medium for the gonococcus, and, indeed, in mixed infections it is imperative to use other media. Of these he considers Wertheim's (1891) and Wassermann's (1897) to be the best, and he concurs with Neisser and Scholtz (1903) in preferring the former. Wertheim's medium is in essence an ascitic-fluid agar medium, while Wassermann's is a pig-serum agar medium, containing in addition a small proportion of glycerin and nutrose.

1 Part of this paper was communicated to the Pathological Society of Great Britain and Ireland, July 8-9, 1910. [Received for publication, August 4, 1910.] Towards the expenses of this research additional grants were kindly awarded by the Camegie Trustees.

2 Excellent reviews regarding media are to be found in the papers of Vamod and Gurd. 
The consensus of opinion, then, is that a proportion of uncoagulated albumin, derived either from animals or man, ${ }^{1}$ is an essential constituent of a good gonococcus medium. Neither hæmoglobin nor urine is of special service, and it is worth noting that the medium most rich in albuminous material is not necessarily the best, because, while small amounts of heated $\left(57^{\circ}\right.$ C.) human serum markedly accelerate growth, large proportions have $n$ distinctly bactericidal action on the gonococcus.

Apart, however, from the actual composition of media, it has of late been recognised that their reaction is also a factor of importance, and indeed in the case of an organism like the gonococcus it may be safely said that the reaction of the culture medium is of prime importance. At first little or no attention was paid to this point, failures with certain batches of medium being simply ascribed to the lack of nutritive qualities in particular constituents. Then, as regards the appropriate reaction of media for the growth of the gonococcus, authorities have differed much. Finger, Ghon and Schlagenhanfer (1894), for example, postulated a reaction frankly acid to litmus as essential. Thalmann (1900), however, laid the optimum reaction between neutrality to litmus and neutrality to phenol-phthalein. Vannod always uses a medium faintly alkaline to litmus, and he further takes the precaution to adjust the reaction of the ascitic fluids required for Wertheim's medium, because exudates, in contrast to blood serum, vary notoriously in composition and in the amount of hydrochloric acid necessary to make them neutral to litmus. Indeed, it is just possible that the neglect of the reaction of the albuminous Huids used in such media may largely explain the lack of uniform success in the employment of Wertheim's and Wassermann's media in different hands. Finally, Gurd (1908) has suggested a medium of the reaction 0.6 per cent. acid to phenol-phthalein.

In view of these differences of opinion, both regarding indicators and the degree of reaction to them, it is of assistance, in assessing the optimum reaction for a gonococcus medium, to consider the behaviour of blood serum and indicators, particularly as it is among human tissue cells that the gonococcus flourishes.

In the early days of culture media Koch used litmus as an indicator, but the modern tendency has been to replace it with a sharper indicator, e.g. phenol-phthalein, which has the advantage of being colourless in acid solutions and pink in alkaline ones. That litmus is alkaline to some salts which are acid to phenol-phthalein is a secondary point. In using phenolphthalein, however, care must be taken to eliminate the effect of carbon dioxide (which is acid to phenol-phthalein). This is best accomplished by making titrations of media as nearly at $100^{\circ} \mathrm{C}$. as possible, for then in the process of sterilisation the reaction will be less likely to be altered by the driving off of dissolved carbon dioxido. $\Lambda$ fixed temperature such as this

\footnotetext{
1 For a discussion of the relative value of human and animal proteins, see the paper by Stross (1905). He decides in favour of human serum.
} 
is also of importance where titrations involving acid salt solutions are made, because electrolytic dissociation varies with the temperature, and, in the language of the ionic theory, acidity is merely an expression of the degree of preponderance of hydrogen ions over hydroxyl ions in the solution.

As is well known, serum reacts acid to phenol-phthalein and alkaline to methyl-orange or to litmus. Pure aqueous solutions of acids or alkalies never so react, but salt solutions, e.g. phosphates, may. Blood serum, in addition to salts, possesses proteins, and these in virtue of their rich amino-acid content can also act either as acids or bases. Now, while blood serum reacts differently to different indicators, or, in other words, is amphoteric to indicators, that does not mean that it is at one and the same time both acid and alkaline, which would be absurd. On the contrary, as Moore (1909) points out, "the actual reaction of the serum is almost that of exact neutrality in the sense of physical chemistry; that is to say, the concentrations of hydrogen ion and hydroxyl ion are about equal." The explanation of the behaviour of serum is that none of the indicators in use change colour just at the chemical or exact neutral point. They only do so when the ratio of the concentrations of the two ions reaches a certain point, different for each; but it must still be a low one if the indicators are to be of any practical value (alizarin and Congo red, for example, are quite insensitive to the weak organic acids). It is the capacity of the proteins for combining with either acid or alkali, as the case may be, which regulates the reaction of the serum in health, and prevents the occurrence of free acid or alkali in the blood, a factor of the greatest importance to the tissue cells, as they cannot bear any appreciable degree either of acidity or alkalinity (Henderson, 1906-1907; Noguchi, 1907).

The phosphates act similarly as powerful neutralisers of free acid and alkali, as is illustrated by the following equations :-

$$
\begin{aligned}
& \mathrm{Na}_{2} \mathrm{HPO}_{4}+\mathrm{HCl}=\mathrm{NaH}_{2} \mathrm{PO}_{4}+\mathrm{NaCl} \\
& \mathrm{NaH}_{2} \mathrm{PO}_{4}+\mathrm{NaHO}=\mathrm{Na}_{2} \mathrm{HPO}_{4}+\mathrm{H}_{2} \mathrm{O}
\end{aligned}
$$

This property of phosphates has led Henderson and Webster (1907), on theoretical grounds, to suggest their use for the maintenance of neutrality in culture media in general, but I have convinced myself of their serviceability in gonococcus media also. Indeed, sodium phosphate may well replace sodium chloride, for not only is the toxic action of the latter on delicate unicellular organisms well known, but in the preparation of meat extracts chlorides are much more readily dissolved out from the tissues, and yet phosphates are essential to perfect nutrition. The value of urine as a constituent of gonococcus media no doubt depends on its phosphate content, and in this connection it may be noted that Wassermann's medium contains a proportion of phosphate in the form of nutrose. Sodium chloride reacts acid to phenol-phthalein, but it is just on the neutral point; di-sodium phosphate is faintly alkaline, a 1 per cent. solution being 0.25 per cent. alkaline; while mono-sodium phosphate is distinctly acid, a 1 per cent. solution being 7 per cent acid. That phosphate acidity is little noxious to bacteria in general is, however, 
shown by the fact that good growths of $B$. coli, B. typhosus, B. dipltheria, and Staphylococcus pyogenes aureus can be obtained on agar media in which sodium chloride is replaced by mono-sodium phosphate $\left(\mathrm{NaH}_{2} \mathrm{PO}_{4}\right)$, and having an acidity as high as 13.5 per cent. to phenol-phthalein ( 5 grms. per litre give roughly 5 per cent. acidity). Even an organism like $V$. cholerce, which is notoriously sensitive to small amounts of free acid, grows well up to an acidity of 2.5 per cent., and faintly at 5 per cent., though no growth at all occurs at 13.5 per cent. The gonococcus is even more sensitive, and while feeble growths are sometimes obtainable on serum-smeared agar 2.5 per cent. acid, I have never seen the slightest growths on 5 per cent. acid media. Similarly, while many organisms grow on media frankly alkaline to phenolphthalein, the gonococeus does not.

The acidity of an average specimen of serum when titrated to phenol-phthalein is equivalent to about 0.65 per cent. of hydrochloric acid, of which about 0.51 per cent. has been estimated by Moore (1909) to represent the combining power of the serum proteins, the remainder being that of the salts.

Now, the supposition that a reaction such as that of blood serum would be suitable for the growth of the gonococcus is confirmed in practice, the best growths of the majority of strains being obtained upon serum agar media, whose reaction is that of only slight acidity to phenol-phthalein. Degrees of reaction beyond the limits of neutrality to an 0.8 per cent. acidity to phenol-phthalein are distinctly unfavourable, though, as indicated above, the range is greater even at isolation with certain strains. In this connection it is interesting to note that, though the American Public Health Association in 1898 adopted 1.5 per cent. acid to phenol-phthalein as the standard for general bacteriological work, Chester in 1901 suggested 0.5 per cent. acid, as he had observed that the higher degree was unsuitable for the growth of many delicate organisms.

The gonococcus medium described in detail below is the outcome of a study of the foregoing considerations. It is a modification which possesses the advantages of transparency, simplicity in manufacture, and suitability for either plates or sloped tubes. It is also very economical of serum, a point of importance where an extensive research is contenplated, and both in my hands and those of friends it has given uniformly excellent results during an extended trial.

A beef neat extract is prepared as usual. To it are added 0.5 per cent. of di-sodium phosphate $\left(\mathrm{Na}_{2} \mathrm{HPO}_{4}\right), 1$ per cent. of Witte's peptone and 2 per cent. of powdered agar. The mixture is placed in a Koch's steriliser, and after the agar has melted the medium is titrated while still hot. For this purpose I take a 5 c.c. sample of the medium, add 2 drops of a $\frac{1}{2}$ per cent. phenolphthalein solution, and then run in a one-twentieth normal sodium hydrate solution from a burette till a faint but permanent pink colour, which distinctly deepens on cooling, appears. This is taken as the end-point, and if the medium is of the correct degree of acidity ( 0.6 per cent. acid to phenol-phthalein or +6.0 on Eyre's scale) 0.6 c.c. of soda solution will have been used (with the above proportions). In practice, however, more alkali is at first required : suppose 2 c.c. were used, then the medium is 1.4 per cent. $(2-0.6)$ 
too acid. This is corrected by adding to the medium in bulk normal sodium hydrate solution in the proportion of 1.4 c.c. to each 100 c.c. of medium (usually rather nore than the calculated figure is actually requisite). The reaction having been adjusted, the medium is filtered, tubed, and sterilised as usual. Care should be taken to avoid prolonged cooking, as this causes a darkening of the medium which, by masking the tints, increases the difficulty of titration. Also, if white of egg is used for clearing purposes, allowance must. be made for the fact that it is usually more acid than the medium. When properly prepared the agar is practically colourless, and it should also possess only a moderate amount of water of condensation. Too moist or too dry a medium is a fault.

For use,- - on the surface of each sloped tube 3 or 4 drops of sterile heated $\left(57^{\circ} \mathrm{C}\right.$. for one and a half hour) human serum ${ }^{1}$ are run and the tubes are then incubated overnight to ensure that they are still sterile. In the case of plates, serum is added to the agar, after it has been melted and cooled to $45^{\circ} \mathrm{C}$., in the proportion of 0.2 c.c. to 5 c.c. of medium. Before being inoculated the mixture must be still further cooled in a thermostat to $40^{\circ} \mathrm{C}$., as the gonococcus is particularly sensitive to heat. Also, as gonococci tend to. die out rapidly at room temperature, it is of great practical importance, especially in winter, to make the inoculations wherever possible direct from the living subject and to place the media in the incubator without delay. Many failures in isolating the gonococcus are attributable to the neglect of this point. Drying should also be guarded against by the use of india-rubber caps, and after isolation it is advisable to make frequent sub-cultures to maintain recent. strains.

Personally, I prefer to isolate by means of successive strokes on slopes rather than by shake plates, though in the case of articular effusions the latter is the better procedure, a quantity of the original fluid or some of the sediment, obtained by centrifugalising before coagulation occurs, being used.

As a rule colonies are visible within twenty-four hours, and are well grown in forty-eight hours, but it is to be noted that occasionally a longer interval (even five days) may elapse before they appear in plates sown with fluids from joints. The pus from acute conditions often yields pure cultures from the beginning, but the cultures from chronic cases are usually more or less contaminated. Little difficulty is, however, encountered in obtaining isolated colonies by the stroke method, and as the gonococcus colonies are readily distinguishable, on account of their moistness and transparency from those of staphylococci, streptococci and diphtheroids of the xerosis type (which are the usual urethral contaminations), pure strains can in most instances be isolated with ease. In the case of the genitals, contaminations are

1 A maternity hospital is a convenient source of this. It should always be obtained under asoptic precautions, as there is no effective means of sterilising fluid serum, and it may with advantage be stored in drawn quill glass tubing in amounts of about 1 c.c. 
minimised by first wiping the external parts dry with sterile gauze before attempting to introduce the platinum loop into the urethra or vagina, as the case may be. It is particularly important to avoid the labial surfaces in the female, as in chronic conditions they literally teem with bacteria of many kinds which would rapidly outgrow the gonococcus. The vagina is an excellent source of cultures in young subjects, but in adults its flora is much more mixed. If, however, care be taken to use the material from a deep source, i.e. from as near the cervix as possible with the aid of a vaginal speculum, pure primary cultures may often be obtained in chronic cases where from an examination of stained films such a thing would appear impossible : the explanation of this lies in the' fact that many species of vaginal bacteria do not grow on this medium under aerobic conditions.

As regards the diagnostic value of cultures, it may be said that in acute gonorrhœal infections of the urogenital tract they are quite unnecessary, the appearances in Gram-stained films being so characteristic. No other organism, the Micrococcus catarrhalis not excepted, gives such a combination of clinical and microscopical appearances in this situation as does the gonococcus.

Cultures are, however, of service in chronic cases where there is a mixed infection, and where after an examination of stained films the nature of some Granu-negative elements may be in doubt on account of their paucity and atypical arrangement. Indeed, my cultural findings serve to accentuate the fact that gonococci may be demonstrated with comparative ease in many genital cases at a time when they present little or no sign of inflammation and infinitesimal discharge. But even in chronic genital affections a diagnosis of a gonorrhœal infection may often be made from an examination of films alone; particularly where polymorphs are met with containing several Gram-negative diplococci of the typical coffee-bean morphology, as such an appearance in properly stained pus films, obtained (with the precautions indicated above for avoiding the superficial flora) from a urethral or vaginal source, is absolutely diagnostic of the gonococcus.

In the eye, an acute ophthalmia, with abundant muco-purulent discharge, may be diagnosed as gonorrhcal upon microscopical examination alone, but the nature of Gram-negative diplococci found in less acute conjunctival affections can only be determined by a study of these in cultures, and in the great majority of instances where this has been done they have been found not to be gonococci (Brons, 1907).

For a diagnosis of the organism elsewhere, isolation and a complete study in culture are absolutely necessary.

In gonorrhcal arthritis gonococci are rarely demonstrable in films, and even with cultures only a small proportion of cases give growths of gonococci. This may be due to the fact that examinations are not made at an appropriately early stage, but more probably the gono- 
coccus (as Beattie has found for his strain of the Streptococcus rheumaticus), flourishes in the capsule rather than in the joint fluid, and this may be coupled with the fact that articular effusions are usually markedly acid to phenol-phthalein. The only case so far observed where gonococci were present in numbers in an articular exudate was one in which there. was a definite traumatic history, and where the fluid, obtained a week later from the affected knee-joint, was largely mixed with blood. The patient, a girl of sixteen years, was the subject of a chronic gonorrhœa.

\section{Cultural Appearances of the Gonococcus.}

At their first appearance on the above described medium (eighteen to. twenty-four hours) the gonococcus colonies are minute, semi-transparent, slightly elevated discs presenting to the naked eye a moist-looking, glancing surface. When examined with a low-power lens they are almost transparent, of a light greyish-yellow colour with transmitted light. They are homogeneous, the ground substance being finely granular, and they have definite uniform margins which under a highpower lens are seen to be very slightly toothed. As the colonies enlarge they tend to remain discrete; the centre thickens and gets more opaque, owing to the development of numerous ovoid coarse granulations; and the margins become scalloped instead of remaining circular (forty-eight to seventy-two hours). Then, owing to a radial plication of the colony, radial striations develop, and concentric rings, due to zones of different degrees of opacity, also appear. Finally, (about a week), still coarser granulations become visible as points of supergrowth throughout the colony, and many attain a considerable size. They are often so white and opaque in contrast to the rest of the colony as to suggest, to the uninitiated, contaminations, but when examined at an early stage with a low-power lens the appearance is exactly that of a superimposed daughter colony. When touched with a platinum loop the growths are readily removed from the medium: they have a distinctly viscous consistence, but they are neither slimy on the one hand nor tenaciously viscid on the other, and cultures fairly readily emulsify.

On agar the growth is less luxuriant, and supergrowths as a rule appear earlier.

In subcultures on Löfler's serum two types of growth may be seen after a week's incubation-most commonly, transparent flattened minute discrete discs with rounded or slightly undulating margins; more rarely, pale, brownish yellow, nail-head-like colonies. These have rounded raised centres, narrow, flat, more transparent, peripheral zones, and undulating margins.

In serum bouillon the common appearance is a finely granular sediment with clear fluid above. The size of the granules is variable, 
as is their consistence, and occasionally there is a transient, faint, uniform turbidity.

No growth occurs on gelatin at room temperature, as growth only takes place at or near incubator temperature. (This statement requires a little modification, because I have obtained a slight growth at $24^{\circ} \mathrm{C}$. on serum agar with two genuine gonococcus strains which had been under cultivation for uine and twelve months respectively. Four other equally old strains did not show any growth at all; neither did twelve more recently isolated strains which were tested at the same time.)

Cultures readily succumb to higher or lower temperatures, and they soon die out if desiccated, though they may remain viable for several weeks if drying is prevented. Frequent sub-inoculations. (weekly) are necessary to satisfactorily maintain growth, as the organisms undergo spontaneous autolysis, swelling to many times their original size, and losing their affinity for stains. This process takes place with particular rapidity in physiological salt solution at incubator temperature, no viable organisms being obtainable after three hours. It should be noted that viable and well-staining elements are frequently obtainable from supergrowths at a time when the rest of the culture is a mass of cellular débris.

In an atmosphere of pure hydrogen growth is much inhibited, but not entirely suspended. Vannod (1907) found no growth at all took place in vacuo, but such a method seems open to the criticism that the delicate cells may have been ruptured by the rapid reduction of external pressure consequent upon attachment to an air pump.

Monphologically, the coffee-bean diplococcus form is the commonest, but tetrads and even appearances of chains of four elements are occasionally seen in culture films. There is much variation in the size of individuals, even of successive generations of the same strain.

From the above description and a scrutiny of the accompanying plates (Plates XV.-XVII. Figs. 1-16) it will be noted that my colonies differ considerably from the classical description of Neisser and Scholtz (1903), and even from that of Gurd (1908), in that they have attained a larger size and shown more differentiation. All my strains have not presented identical appearances in culture, but this is hardly to be expected, as even on different parts of the same plate the individual colonies of one strain are not always alike. The thinner and drier the layer of medium the smaller and more opaque are the colonies, development often ceasing in forty-eight hours. Transparency of margin is not constant, some strains which on the whole show a less extensive growth being comparatively opaque to the edge. Other colonies, again, after some days develop a thickened margin, leaving a more transparent zone between it and the centre; and the margin is sometimes more deeply bayed than the word 
"scalloped" implies. The granular centre is occasionally little developed, even lacking, and so may be radial and concentric striations.

Thus no single cultural character is absolute, but the combination of characters - greyish-bluish-white moist appearance, transparency and scalloping of margin, granularity of centre, concentric and radial striation and slight viscidity - is of great importance for the diagnosis of gonococcus colonies. Indeed, in spite of the opinion of Elser and Huntoon (1909), cultural characters are of very considerable service in differentiating the gonococcus from allied organisms.

\section{Differentiation of the Goxococcus from Allied Organisms.}

The pathogenic organisms which fall to be differentiated from the gonococcus are the meningococcus and the Micrococcus catarrhalis, but to these must be added a group of saprophytic catarrhalis-like organisms common in the sputum and naso-pharnyx, to which, on account of the fact that their growths are frequently pigmented, the term chromogenic Gram-negative cocci has been applied by Elser and Huntoon. The meningococcus is easily first in importance, but the "chromogenic" Gram-negative cocci also require consideration, for they are practically ubiquitous and bence are frequently being enconntered in material obtained from situations exposed to the air.

Alike in Gram-negativity, morphology and tendency to intracellular disposition, these organisms all resemble one another closely; indeed, the resemblances do not stop with the enumeration of these three points. No one, however, doubts that they are related, but the question which has to be settled concerns the actual degree of the relationship.

The three main organisms were originally isolated from, and are commonly associated with, pathological conditions in very definite situations in the human subject; but with the progress of research it has been shown that their energies are not absolutely confined to these particular localities. The gonococcus, for example, in addition to genital and conjunctival affections, can induce arthritis and endocarditis; the meningococcus likewise sometimes affects the conjunctiva, the endocardium and the joints. But so far, in spite of the prevalence of gonorrhcea and the periodical occurrence of great epidemics of cerebro-spinal fever, there is no satisfactory evidence that the gonococcus ever causes a meningitis or the meningococcus a urethritis, although supposed cases of gonococcal meningitis have been described. This is the more remarkable in that, on the one hand, gonorrhcal metastases are common enough elsewhere, and that, on the other, meningococci can frequently be isolated from the urine of cerebro-spinal fever cases in which there is not the slightest evidence of genito-urinary inflammation. That the meningococcus should single out the cerebro-spinal meninges, particularly of the young, and the 
gonococcus, the urethra of the adult (or the conjunctiva, urethra, and vagina of the child), cannot be satisfactorily explained on the mere chances of accidental inoculation: rather must it be considered as definite evidence of a relation between the susceptibility of the host and the pathogenicity of the invading organism, so that there are $d$ priori grounds for considering that these organisms belong to distinct species.

The facts regarding pathogenicity just narrated also serve to indicate the difficulties of differentiation in this group of bacteria as, even in this respect, the properties of the organisms in question are not sharply defined. Human urethral inoculation would probably be a critical diagnostic test as to whether an organism was a gonococcus or not, but unfortunately it is a criterion which cannot be applied in practice. The lower animals, again, being so little susceptible to the organisms of this group, we are forced to seek for differential tests in other laboratory procedures, and the question is whether they are adequate for the purpose. In the literature, at all events, the greatest differences of opinion are to be found regarding this point.

Before passing to a consideration of these in detail it is well to realise, as has already been pointed out in discussing the isolation of the gonococcus, that not only is there variability in the characters and properties of strains from similar sources (e.g. gonococci isolated from different cases of gonorrhœa), but there is also a certain degree of variability in those of individual strains (see Plate XV. Figs. 9, 10, which show the varying appearances of colonies of the same strain even when grown on the same culture plate). In other words, whatever be the conception or definition of bacterial species, varieties are of necessity implied within it, for no short description of an organism can be given to which it will always conform. Indeed, where single characters of organisms are alone considered, almost innumerable variations occur. The results of biometrical studies have, however, shown that descriptions averaged from a consideration of many characters are of much more service in the classification of biological data than are those based upon single ones; and it will be my object to show that if the properties or characters elicited by a laboratory study of these organisms be considered in this light, then certain fairly well-defined groups of characters will be found to pertain to the organisms isolated from particular localities (or classes of affections) in the body; that, in fact, a gonococcus type, a meningococcus type, and a micrococcus catarrhalis type exist, the organisms of the first being associated chiefly with gonorrhœeal, those of the second chiefly with meningeal, and those of the third chiefly with catarrhal (respiratory) conditions in man; and that while border-land organisms do exist, it has yet to be proved that a typical organism of one class can be artificially converted to a typical organism of another; and finally, that on the theory of probabilities a diagnosis of an organism may be made in some circumstances from a few characters with almost 
absolute precision, but that in other situations every resource of bacteriology must be taxed before one is able to recognise an organism with any degree of certainty.

By laboratory procedures we can study cultural characters, fermentative activities, and immunity reactions. The conditions of growth and cultural appearances of the gonococcus having already been dealt with, those of the other organisms may next be reviewed.

\section{The Meningococcus.}

This organism is undoubtedly a delicate one, but while in culture it multiplies more rapidly and is more prone to spontaneous autolytic degeneration than the gonococcus, it is on the whole less susceptible to the influences of cold, heat and sodium chloride, and is much less sensitive to the reaction of the culture medium. Even at the time of isolation the range of reaction compatible with growth is a wide one. A reaction of about 1.5 per cent. acid to phenol-phthalein (slight alkalinity to litmus) does excellently, but in subcultures the organism readily accommodates itself to other degrees both of acidity and alkalinity. The difficulty in the cultivation of the meningococcus is not in getting primary growths but in maintaining them. It is therefore of considerable importance to subculture daily for a time, as at first the organisms tend to die out very rapidly, and of course desiccation must be guarded against. Sub-inoculations on ordinary agar often grow well, and primary isolations are possible with it, but stocks are best maintained on serum agar slopes. Subcultures should be made every four or five days for safety, although strains can sometimes be revived in serum bouillon at the end of a fortnight.

An excellent method of isolation is by plating direct from the cerebro-spinal fluid with a serum-agar mixture (mutatis mutandis, the technique is identical with that used for the isolation of the gonococcus from joints). Colonies are usually visible within twenty-four hours, though it may be forty-eight hours before they appear. Delays in plating are to be guarded against. The exact reason why meningococci should die out in tapped exudates, which have stood for a time, is not quite clear. They do not always do so, as I have on two occasions obtained abundant cultures where the fluid had been kept overnight in ice. Perhaps leucocytic ferments liberated by the disintegration of polymorphs (Hiss and Zinseer, 1908) may have some share in the process, although, as Flexner (1907) has shown, the autolytic ferments produced by the cocci themselves are also noxious.

Chapoteaut's peptone agar, with or without 1 to 2 per cent. glucose, has in Wassermann's hands given botter growths than Witte's peptone agar, but of this peptone I have no experience.

The medium (sheep's blood-maltose-ascitic agar) suggested by Esch (1909) for the rapid isolation of the meningococcus for diagnostic purposes has quite a good formula, but its serviceability is not so great as Esch supposes. 
In the first place, it is no easier to prepare than Buchanan's modification of Löffler's serum (glucose and neutral red). Secondly, in many cases excellent primary growths are obtainable on other media within eighteen hours from cerebro-spinal exudates ; and finally, the presence of a Gram-negative diplococcus in such an exudate is presumptive evidence that it is a meningococeus, and serum treatment should be begun at once without waiting for cultural confirmation.

\section{Cultural Appearances.}

In subcultures on serum-agar meningococcus colonies are sometimes visible within six hours. After eighteen to twenty-four hours there is usually abundant growth. The colonies are minute, semi-transparent, greyish-white, slightly elevated dises with a moist-looking surface. On the whole, they are more opaque, naked-eye, than the average minute gonococcus colonies. Examined with a low power, the most striking and highly diagnostic feature (it is rarely absent) is a very transparent outer zone, the actual margin being almost invisible (see Plate XVIII. Fig. 19). The general groundwork of the colony is semi-transparent, and of a faint yellowish-white colour when viewed by transmitted light. With a higher power it is seen to be made up of rather coarser granules than those of gonococcus colonies.

As the colonies increase in size they tend to remain circular and discrete. Further, they usually remain homogeneous in appearance. The coarse ovoid secondary central granules so common in gonococcus colonies, and which give the distinction between centre and periphery in them, are not as a rule met with. There is little or no tendency to the plication of the colony, though slight surface radial striæ may be seen in old colonies (three to five days). At this stage marginal thickenings may appear, and from these lateral processes tend to develop. Thus the margin assumes an irregular but not a scalloped appearance. Growth commonly ceases at this stage, but rarely old colonies (tive days and more) continue to enlarge by taking on a more sprawling type of growth (Plate XVIII. Fig. 21). The lateral processes further develop, and soon the margin becomes deeply bayed, and when magnified it may be seen to possess secondary scallopings very similar to those of gonococcus colonies. In the central portions of these old meningococcus colonies crystalline deposits are a marked feature, and give rise to a central granularity simulating that of gonococcus colonies, due to the development of true coarse ovoid granules. (Crystalline deposits, it should be added, are also encountered in gonococcus colonies, concentric striation being in part due to them.) Super-growths may appear anywhere on old colonies, but they do not offer the same contrast as the gonococcus colonies do, on account of the comparative opacity of the whole colony, and indeed they are not so commonly encountered.

This late type of growth, by which meningococcus colonies occasionally come to superficially resemble those of the gonococcus, is a very common one with old circular colonies of many organisms, and it reaches a high degree in the members of the catarrhalis-like group. It is probably to be related to a diminished vitality of some of the organisms of the colony, consequent upon alterations induced in the medium by the bacteria themselves (or by drying), with the result that multiplication does not occur equally rapidly at all points of the circumference.

The growths like gonococcus colonies are slightly viscid. They are easily removed from the surface of the medium, and they readily emulsify.

On agar the growth is not so luxuriant, as a rule, but it presents similar features to that on serum-agar.

The meningococcus grows readily in bouillon, a small proportion of serum materially aiding growth, with the formation of a uniform fairly dense turhidity. Later a finely granular sediment is deposited.

No growth occurs on gelatin at room temperature. 
A delicate microscopical growth may sometimes be obtained on potato.

Under anaerobic conditions growth is inhibited, but not entirely suspended.

MORPHOLOGICALLY, in stained films of cultures the meningococcus simulates the gonococcus exactly. The fact that meningococcic diplococci are sometimes very minute is of no diagnostic value.

\section{The Micrococcus Catarrhalis.}

This organism is usually described as growing readily on agar, and more slowly on gelatin at room temperature. It is also commonly stated to be a comparatively resistant organism. These statements are, however, true only in a general way. I have met with undoubted strains which could not be grown on plain agar, of varying degrees of acidity, until they had been subcultured for several generations on serum media, and some could not be coaxed to grow at all on gelatin. at room temperature (see also Gordon, 1905). Then while, as a rule, catarrhalis strains survive well in culture, occasionally these have tended to die out just as rapidly as those of the meningococcus.

As in the case of the meningococcus, the range of reaction is a wide one, indeed rather more so, but a medium slightly alkaline to. litmus serves excellently. The best isolation method is by serum-agar plates, with or without the addition of an indicator, as in Buchauan's medium, the sputum or naso-pharyngeal mucus having been emulsified in bouillon and diluted to an appropriate degree. One rarely fails to obtain them from any sputum-bronchitic, phthisical or resolving pneumonic-though personally $I$ have never met with a genuine Micrococcus catarrhalis infection as described by Dunn and Gordon and others.

\section{Cultural Appearances.}

The young colonies on agar or serum-agar are usually definitely raised, glistening discs of a greyish to creamy white tint. Contrasted with meningococcus colonies, they are on the whole thicker, more opaque, and less moist; indeed, from their opaque white varnished appearance at a slightly later stage the growth simulates that of a delicate Staphylococcus pyogenes allus. Viewed by a low-power of the microscope, they are brownish-yellow in colour, with distinct thick circular uniform margins. The groundwork shows minute granulations at the margin, usually becoming very coarse and opaque towards the centre. As the colonies enlarge the centre appears darker and becomes more raised, giving a fairly diagnostic appearance of a round-headed nail flattened peripherally. Sooner or later the margin usually becones irregular, finally presenting a somewhat jagged outline to the naked eye (see Plate XVIII. Fig. 22).

Catarrhalis strains vary, and sometimes by taking on a less luxuriant typeof growth simulate the meningococcus in gross appearance on slopes, but thereis usually little difficulty in differentiating them when single colonies are observed in detail.

The growths are readily removed from the surface of solid media, and are, as a rule, more friable than viscid in consistence. Cultures are readily broken. $\mathrm{up}$, but there is a great tendency to spontaneous agglutination, and emulsions are not permanent.

In bouillon the commonest appearance is a dense granular sediment. without turbidity. On shaking, a dense uniform turbidity results, but it. 
speedily settles into the granular deposit again. Occasionally, if the inoculation has been made at the junction of the surface of the fluid with the tube wall, and the tube kept still in the incubator, a thick pellicle with stalactites forms on the surface, but this readily precipitates when the tube is shaken and allowed to stand. Such surface growths are obtainable, but with greater difficulty, also in the case of the meningococcus. They are extremely uncommon with gonococci.

On gelatin at room temperature, growth usually occurs slowly without. liquefaction.

A true Micrococcus catarrhalis is never pigmented, though the central. portions of old colonies appear brownish by transmitted light.

MoRPHOLOGICALLY, the Micrococcus catarrhalis presents, as a rule, larger elements in films than either the gonococcus or the meningococcus. The large spherical forms that appear in twenty-four to forty-eight-hour cultures are rather more retentive of the stain in Gram's process than are the corresponding forms in the case of the other two organisms.

\section{Other Gram-negative Cucci found in the Respiratory Tract.}

Von Lingelsheim (1906) described five other organisms, which differed from the Microroceus catarrhalis in pigment production, agglutination and fermentation reactions:-

(1) Micrococcus pharyngis siccus; (2) Micrococeus pharyngis cinereus; (3) Diplococcus flavus I.; (4) Diplococcus pharyngis flavus 11.; (5) Diplococcus. pharyngis flavis $\mathbf{I I r}$.

Gordon (1905) had also noticed the occurrence of atypical fermenters, and described in all three varieties of catarrhalis organisms.

The colonies of (1) are, in the early stages, like those of the Micrococcus: catarrhalis, but they have a slightly yellower tint. Later they usually present a corrugated surface, not unlike that of the acid-fast bacterial growths. The growth distinguishes itself by its firm adhesion to the medium (Plate XVIII. Figs. 23, 24).

The others are sometimes also distinguishable to the naked eye by the colour of their colonies, particularly when grown on Löffler's serum or glucose-containing media. (2) is greyish-white ; (3), greenish-yellow ; (4), golden-yellow ; and (5), light yellow. Pigment production is, however, very variable, even in the case of such an organism as the Staphylococcus pyogenes aureus, so that further differential tests are necessary. The following table, taken from von Lingelsheim, shows the fermentative capacities of his varieties. The results are those obtained at the end of twenty-four hours.

\begin{tabular}{|c|c|c|c|c|c|c|c|c|c|c|}
\hline Organisms. & 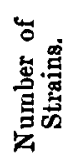 & 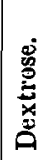 & 兽 & 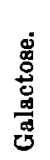 & 遏 & 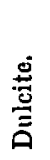 & 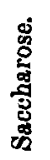 & 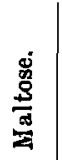 & 总 & 离 \\
\hline 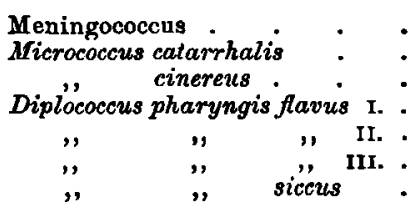 & $\begin{array}{r}83 \\
21 \\
4 \\
6 \\
4 \\
8 \\
4\end{array}$ & $\begin{array}{l}+ \\
0 \\
0 \\
+ \\
+ \\
+" \\
+\end{array}$ & $\begin{array}{l}0 \\
0 \\
0 \\
+ \\
+ \\
0 \\
+\end{array}$ & $\begin{array}{l}0 \\
0 \\
0 \\
0 \\
0 \\
0 \\
0\end{array}$ & $\begin{array}{l}0 \\
0 \\
0 \\
0 \\
0 \\
0 \\
0\end{array}$ & $\begin{array}{l}0 \\
0 \\
0 \\
0 \\
0 \\
0 \\
0\end{array}$ & $\begin{array}{l}0 \\
0 \\
0 \\
0 \\
0 \\
0 \\
0\end{array}$ & $\begin{array}{l}+ \\
0 \\
0 \\
+ \\
+ \\
+ \\
+\end{array}$ & $\begin{array}{l}0 \\
0 \\
0 \\
0 \\
0 \\
0 \\
0\end{array}$ & $\begin{array}{l}0 \\
0 \\
0 \\
0 \\
0 \\
0 \\
0\end{array}$ \\
\hline $\begin{array}{l}+ \text { indicates } \\
\text { and }+" \text { stro }\end{array}$ & & & & & & & & & & \\
\hline
\end{tabular}


For comparison, Gordon's findings are also tabulated :-

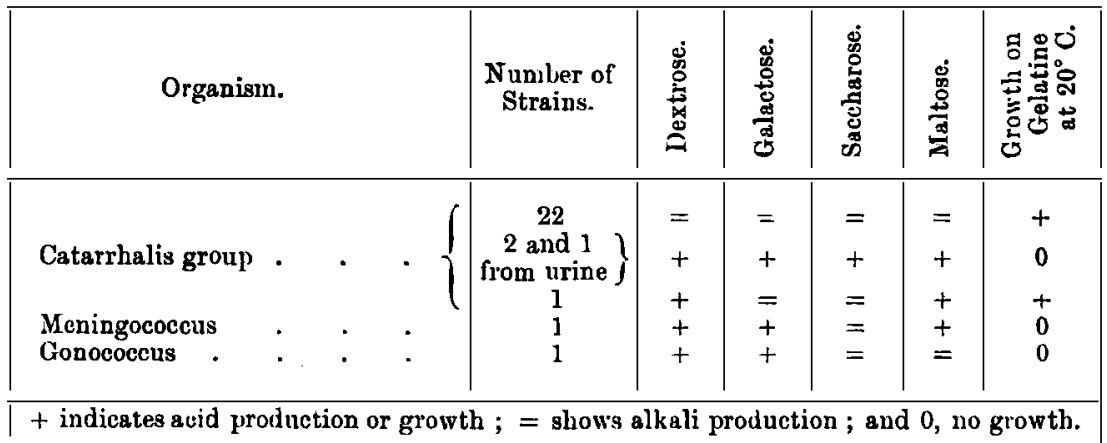

Elser and Huntoon (1909) divided the chromogenic Gram-negative cocci of the naso-pharynx into three groups. The members of their chromogenic group I. have all the same fermentation reactions (producing acid in dextrose, maltose, lævulose and saccharose), but differ among themselves in agglutination renctions : their pigment is a greenish-yellow. The chromogenic group II. comprises organisms of the same species (fermenting dextrose, maltose and lævulose); it is apparently synonymous with von Lingelsheim's Diplococcus. plaryngis flavus $\mathrm{I}$. The members of the chromogenic group III. differed only in minor inconstant features from those of the chromogenic group 1.

One great feature of these catarrhalis-like organisms is their tendency to revert on long cultivation to a scarcely pigmented, rather moist semi-meningococcic type of growth already mentioned as occasionally assumed by the Micrococcus catarrhalis itself. On first isolation, however, they are fairly readily distinguishable by cultural appearances from the meningococcus.

They, too, should be isolated on a serim medium, preferably, as Elser and Huntoon point out, a glucose-containing one to accentuate pigment production.

The organisms of this class which I have encountered have all given deposits in bouillon, without turbidity. Surface scums are common. On shaking, the sediment has either risen in the form of a tenacious column or has been disseminated throughout the fluid in granules of varying degrees of coarseness.

On solid media supergrowths were rarely observed. None liquefied gelatin and some did not grow on it at room temperature.

\section{General Conclusions from Cultural Characters.}

From the foregoing details it will be seen that the Micrococcus catarrhalis is the most and the gonococcus the least vegetative organism of the three; that occasionally the vegetative capacity of the Micrococcus catarrhalis is very much less; and that with prolonged artificial cultivation a greater degree of vegetative capacity can sometimes be impressed on the gonococcus than it possesses at isolation. 
So with practically every other cultural character, variations occur, but in the vast proportion of instances cultural characters are of considerable service in the differentiation of these three organisms.

The following features are all highly characteristic of the gonococcus:-Delicacy of growth and its comparative restriction to serum media of a particular reaction; a greyish-bluish-white moist appearance of surface colonies which are radially plicated and concentrically striated, and have granular centres and scalloped margins; and poor growth (slight granular deposit) in serum bouillon.

The meningococcus gives a more luxuriant and more rapid growth. It grows well on a wide variety of media and forms a uniform turbidity, with deposit later, in serum bouillon. Its colonies are comparatively undifferentiated greyish-white, but the delicate, almost invisible margins of young colonies are very typical.

The Micrococeus catarrhalis is the most opaque and active grower of the three, it being the only one which grows on gelatin at room temperature. In serum bouillon it gives a scum and granular deposit without turbidity. Its colonies have an opaque white varnished appearance; later their centres become raised and their margins crenated.

\section{Fermentative Activities.}

There is considerable difference of opinion as regards the best method to employ for the elucidation of fermentative activities. Some prefer solid media and others liquid. I have used both, but prefer the former for this group. Whatever may be the case with other organisms, I, unlike Trautmann and Fromme (1908) and Arkwright (1909), have found little tendency for the tubes to turn acid and then become alkaline again at places if drying is prevented by the use of india-rubber caps, and I have uniformly observed my strains for a period of a month. Solid media possess the great advantage that the nature and extent of the growth can be observed from the beginning, and where serum is a constituent it is important to know that there are no contaminations. Further, with delicately growing strains it is necessary to be sure that growth has taken place, and fluid media are not the best. for observing this in the case of the gonococcus. Again, as my work has shown that gonococci can be grown on plain agar, of reaction faintly alkaline to litmus (better, when serum has been smeared on the surface, though this is not necessary in a great proportion of instances), there is a further advantage that if a fermentable substance be added to such agar the basis of the medium is of definite and constant composition.

$A$ point of the greatest importance in the preparation of these media is to avoid alteration of the composition of the fermentable substances in the process of sterilisation, the proclivity for complex carbohydrates and glucosides to undergo hydrolytic dissociation when treated with acids, 
alkalies, etc., being well known. This is avoided by sterilising them separately in distilled water for ten minutes at $110^{\circ} \mathrm{C}$, and not when they are in the agar medium. For careful work all vessels must be of Jena glass, well steamed before use. Ordinary glass yields a considerable amount of alkali to the contained fluid during sterilisation, and at best these organisms are feeble fermenters. Then the sugars, etc., must be of the purest; dextrine, for example, must not contain dextrose. I have used both Merck's and Kahlbaum's products. Litmus is often decolorised when boiled in carbohydrate-containing. media; this is also avoided by separate sterilisation.

The following is the method of preparation in detail :- a beef meat extract is prepared as usual. It is inoculated with $B$. coli, and the latter allowed to grow in it for thirty-six hours, to exhaust the fluid of muscle carbohydrates. (As shown by Rivas, 1907, B. coli does not completely exhaust a meat extract of its fermentable substances. It does so for members. of its own class, for the organisms of this group and of some others, but as I have been able to confirm there still remain substances fermentable by, e.g., streptococci. It is therefore necessary in the case of these latter organisms to use a pure peptone-water agar medium. Controls in any case should always be employed. One batch of coli-exhausted (twenty-four hours) medium, for example, had its control tubes fermented by a single meningococcus strain, while ten other strains did not ferment them.) Peptone and salt are now added, and the medium heated to $100^{\circ} \mathrm{C}$., in a Koch's steriliser. It can usually be filtered clear through filter paper by the adoption of this device, which is a great saving of time over the older method of first passing through a Chimberland candlo to remove the colon bacilli. Powdered agar 2 per cent. is added to the clear filtrate, melted in it, and the reaction adjusted to very faint alkalinity to litmus. It is next cleared with egg-white, filtered, and measured into separate flasks, which are then sterilised in the Koch steamer for short. periods on three successive days.

The litmus (Kubel-Tiemann's solution was used throughout) is sterilised. alone in the autoclave at $110^{\circ} \mathrm{C}$. for ten minutes.

The carbohydrates, etc., are made up in 10 per cent. solutions in previously sterilised distilled water, and are also autoclaved at $110^{\circ} \mathrm{C}$. for ten minutes.

While the fluids are all hot, they are mixed in the following proportions : 85 c.c. of agar, 5 c.c. of litmus, and 10 c.c. of the respective sugar solutions : and carefully run into previously sterilised tubes. The medium is immediately sloped. Thus obtained it is perfectly clear and sufficiently tinted with litmus to indicate its faintly alkaline reaction (a one-thousandth normal soda solution produces no change in litmus, but a one-hundredth is distinctly alkaline). The medium thus prepared is usually sterile, but the tubes should always be incubated for twenty-four hours before using, to ensure that they really are sterile.

With such media I have obtained very uniform results. All my strains (with one possible exception) isolated from gonorrhoeal sources: fermented, with the production of acid but not of gas, dextrose, and dextrose alone of the following nineteen substances:-

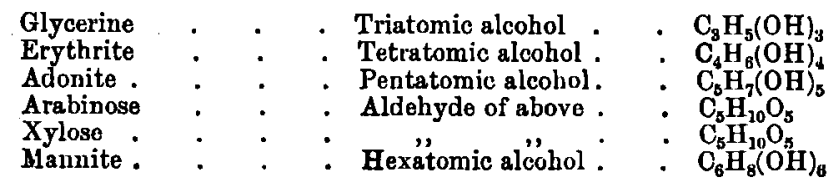




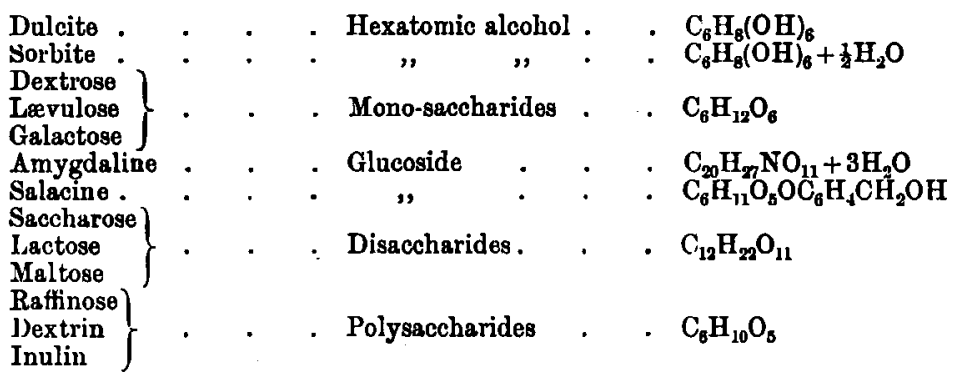

The meningococcal strains which were thus tested all fermented maltose in addition to dextrose. Of the Gram-negative cocci isolated (from sputa and old urines) apart from gonorrhoal and cerebro-spinal fever cases, four types of fermenters have been encountered.

The results are given in tabular form on page. 94.

The atypical strain alluded to above was isolated on January 30,1909 , in pure culture (several colonies grew on the original plate) from the knee-joint of a woman at. 31. Only one joint was affected, and the illness, which dated from December 21, 1908, was clinically regarded by Sir George T. Beatson as one of gonorrhceal arthritis. Superficially from cultural characters, conditions of growth (meagre save on gonococcus medium), and appearances in films, it looked and was regarded as a gonococcus. After a course of vaccine therapy the patient left hospital improved early in March 1909, but she did not return to report. Six months later the fermentation reactions of the organism were studied, and it was found to give those of a Microcsceus catarrhalis. Then it was also found to grow slowly on serum agar at $24^{\circ} \mathrm{C}$., but not on gelatine. In serum bouillon it gave a granular deposit. The surface growths on serum media were more viscid than friable, and gave permanent suspensions in salt :solution. On the gonococcus medium its vitality was considerable, subcultures taking after six weeks at $37^{\circ} \mathrm{C}$. The appearances of colonies are shown in Figs. 77 and 18, Plate XVII. Naked eye, they are rather more opaque than the average gonococcus colonies. So far it has not yielded an active complement-deviating serum in a rabbit, but like a genuine gonococcus strain it deviates comparatively little with an active meningococcic serum. It is unfortunate that the genitals were not also bacteriologically investigated and that the characters of the organism were not studied at length on isolation, but the fact remains that it is an atypical Gram-negative organism from a joint.

The only other reference in the literature to the possibility of such a finding is that given by Mallory and Wright (1904), who state that "we have met with a Gram-decolorising coccus in an arthritis of the knee, clinically of gonorrhoal origin, which, in cover-grlass preparations from the exudate, was regarded as a gonococcus, but which was found not to be that organism by a study of it in culture." Dr. J. Homer Wright has kindly furnished me with photographs of his colonies and details which have not been published elsewhere. "The patient was a woman æt. 39. Two days before delivery of a child her right ankle and a joint of her right thumb became red, swollen, and painful. The next day the right knee became swollen. The child developed gonorrhœal ophthalmia. Three weeks after delivery she entered the hospital for operation on the knee, which had become flexed and fixed on account of pain. It was swollen, hot, and tender. She had a profuse vaginal discharge which contained micrococci, decolorising by Gram's method and intracellular." Unfortunately these were not contrasted in culture with the strain from the knee. The latter was isolated with ease on blood agar and 
from a survey of its characters there is no doubt that it was an unusually vegetative strain-e.g. in subculture it grew on plain agar, and on Löffler's serum in the form of minute colourless colonies, while in glucose bouillon it grew in the form of a viscid sediment with slight clouding of the medium, later there being a tendency to the formation of a delicate surface pelliclebut as its fermentative powers were not estimated its exact nature must remain undetermined.

\begin{tabular}{|c|c|c|c|c|c|c|}
\hline $\begin{array}{l}\text { Clinical } \\
\text { Type. }\end{array}$ & Source. & 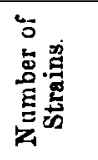 & 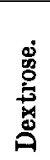 & 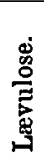 & 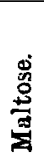 & 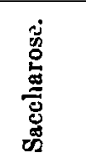 \\
\hline $\begin{array}{l}\text { Gonococcal } \\
\text { Strains. }\end{array}$ & $\begin{array}{l}\text { Acute urethritis, male } \\
\text { and female, adults } \\
\text { Chronic urethritis, male } \\
\text { and female, adults } \\
\text { Acute vaginitis, infants. } \\
\text { Chronic vaginitis (in- } \\
\text { cluding cervix), adults } \\
\text { Acute ophthalmia, in- } \\
\text { fants . } \\
\text { Arthritis (genitals bac- } \\
\text { teriologically examined } \\
\text { and positive) } \\
\text { Arthritis (genitals not } \\
\text { exanined). }\end{array}$ & $\left.\begin{array}{r}10 \\
6 \\
5 \\
4 \\
3 \\
6\end{array}\right\}$ & + & - & - & - \\
\hline $\begin{array}{l}\text { Meningococca } \\
\text { Strains. }\end{array}$ & 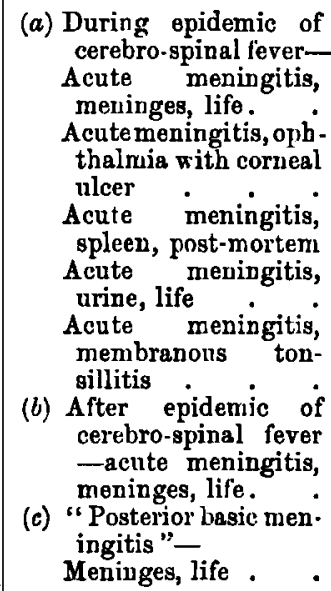 & \begin{tabular}{l|l}
1 & \\
4 & 31 \\
1 & 31
\end{tabular} & + & $=$ & + & $=$ \\
\hline $\begin{array}{l}\text { Catarrhalis } \\
\text { Straius. } \\
\\
\text { Catarrhalis-like } \\
\text { Strains. }\end{array}$ & $\begin{array}{l}\text { Sput um bronchitis, } \\
\text { phthisis, pneumonia } \\
\text { Urine exposed to air : } \\
\text { Urine exposed to air } \\
\text { s pu tum bronchitis, } \\
\text { phthisis, pneumonia: } \\
\text { Sputum bronehitis : } \\
\text { Sputum bronchitis : }\end{array}$ & $\begin{array}{l}6 \\
1 \\
4\}_{6}^{6} \\
2 \\
2\end{array}$ & $\begin{array}{l}= \\
+\end{array}$ & $\begin{array}{l}+ \\
+ \\
=\end{array}$ & + & $\begin{array}{l}=(1) \\
+(2) \\
=(3) \\
=(4)\end{array}$ \\
\hline \multicolumn{7}{|c|}{$\begin{array}{l}\text { Indicates fermentation with acid production ; }- \text { indicates production of a } \\
\text { slight alkaline reaction; and = of a marked alkaline reaction. } \\
\text { (1) These were typical Microcoecus catarrhalis struins. } \\
\text { (2) These gave very tenacious growtls, Micrococcus pharyngis siccus strains (Plate } \\
\text { XVIII. Fig. 23). } \\
\text { (3) These gave greenish.yellow growths. } \\
\text { (4) These gave opaque yellowish-white growths (Plate XVIII. Fig. 24). } \\
\text { This organism is referred to in detail on p. 93. }\end{array}$} \\
\hline
\end{tabular}


As regards the rate at which the fermentative changes occur; meningococcus and catarrhalis results are usually well marked in forty-eight hours, while the gonococcus requires four to five days. At the end of a month's incubation the results are the same. The rapidity with which non-fermented tubes, in the case of meningococcus and catarrhalis strains, become markedly alkaline is strikingly in contrast with the very slow development of a much less alkaline reaction in the gonococcus tubes, and is of diagnostic value.

Some gonococcus strains ferment dextrose more feebly than others.

Some meningococcus strains also ferment dextrose less rapidly than. they do maltose.

The definiteness of these carbohydrate findings gives another set. of characters of great specific importance, and they may be added to those given on $\mathrm{pp} .90-91$.

It must be stated, however, that all observers have not obtained such uniform results. If one excludes galactose from Gordon's original results they essentially confirm mine. (I have prepared his medium with all the precautions outlined above-pp. 91-92-designed to prevent alteration of the sugars, and I have used a pure galactose. The results obtained were then identical with my own obtained on solid media.) Von Lingelsheim (1906) did not study the gonococcus, but his meningococcus results are confirmed by mine. More recently Brons (1917), Rothe (1908) and Elser and Hustoon (1909), are all in essential agreement.

It is a striking thing that the least consistent results have been obtained by the users of fluid media, e.g., Arkwright (1909) found levulose fermented by several meningococcic strains when it was dissolved in broth but not when in plain peptone water.

The vast majority of workers agree that both dextrose and maltose are fermented by the meningococcus:-Gordon (1905), von Lingelsheim (1905), Andrewes (1906), Dunham (1906), Goodwin and von Sholly (1906), Kutscher (1907), Stoevesandt (1908), Symmers and Wilson (1909), and Arkwright. (1909). Differences exist regarding galactose, lævulose and dextrine, but if the reports are scanned it will be found that due care has not been taken to procure pure substances or to avoid alterations consequent upon sterilisation to which galactose and lævulose are particularly prone. The accounts of fermentations of galactose, levulose and dextrine can therefore be passed by. Arkwright's descriptions of alterations of fermentative properties with artificial cultivation are highly interesting, e.g., he isolated one strain which fermented no sugars on isolation, then maltose alone for some months, and finally, after ten months' artificial cultivation, dextrose and maltose. Another strain fermented both on isolation but lost the capacity to ferment either. He has also obtained strains which at no time fermented either dextrose or maltose, but I havo not any parallel observations of my own, though I have had some strains in cultivation for nearly two years.

Regarding the gonococens:- of two strains tested by Arkwright (1909), the one fermented dextrose and maltose, as had been recorded by Wollstein (1907) and by Gurd (1908)-the latter also got fermentation of mannite with five strains-and the other fermented dextrose and galactose, as Gordon (1905) and Shennan and Ritchie (1908) had also found for one strain each. Watabiki (1909) studied fifteen strains in a 50 per cent. horse-serum peptone water medium and found they all behaved alike-dextrose, maltose, dextrine and levulose being fermented, while galactose, lactose, saccharose, mannite, dulcite and inulin were unaffected. No reliance, however, can be placed on 
results obtained in a medium prepared as his was. Rothe (1908) and Elser and Huntoon (1909)-fifteen strains-found, as have $I$, that the gonococcus only fermented dextrose.

Indol is useless as a differential test, as in my experience it is not produced by any of the organisms.

\section{IMMUNITY ReActions.}

If diversity of opinions and results can exist regarding fermentative capacities there is even more scope for this among immunity phenomena.

Agglutination, bactericidal action, complement deviation and opsonic action have all been studied by various observers.

It ought to be borne in mind that one type of immunity reaction may be of differential value in some groups and useless in others. Agglutination, for example, is of great service in the typhoid-coli group, but valueless in the dysentery group (Fisher, 1907). Then anti-substances do not by any means vary pari passu, e.g. a serum may be actively opsonic yet not possess much complement-deviating power. Finally, a marked degree of immunity may exist without demonstrable agglutinating, bactericidal or anti-infectious substances (which could confer passive immunity) being present in the blood serum, as has been pointed out by Strong (1908), in the case of immunity to plague. Although there was a slight degree of complement-deviating power and a slightly increased opsonic action, they were infinitesimal compared to the degree of immunity the animals possessed.

Agglutination and opsonic action. - Agglutinating and opsonic reactions have been considered important by Arkwright (1909), and by Houston and Rankin (1907), for the differentiation of epidemic and :sporadic strains of meningococci; but, as demonstrated by Macgregor (1908), meningococci may suddenly, in the course of artificial cultivation, lose their susceptibility to opsonic action, and old cultures, as Houston and Rankin themselves acknowledge, are often phagocyted in the presence of normal serum. As regards agglutinins, Symmers and Wilson (1909) and Elser and Huntoon (1909) note that old cultures are as a rule twice as easily agglutinated as recent ones, and Arkwright acknowledges this in general. Indeed, a close scrutiny of the latter's Table VII. (p. 112), shows agglutination to vary with the same strain and sera at different times. Stoevesandt (1908) has pointed out that the sera of patients suffering from other diseases may agglutinate the meningococcus as actively as the sera of many cerebro-spinal fever patients ( 1 in 30 to 1 in 100 within twenty-four hours). Still more to complicate matters, Elser and Huntoon (1909) have shown that the nature of the medium on which cultures are grown exerts an effect upon their agglutinability (serum acting deleteriously), and that under certain circumstances centrifugalisation of an immune serum causes a reduction of its agglutinating value. 
Enough has perhaps been said to emphasise the extreme complexity of the subject of agglutinins and opsonins in connection with this group, and to show the futility of using small differences to subdivide the families, and also the necessity for many controls if these methods are to be used for clinical diagnostic purposes. Bruckner and Christéanu (1906) found that an anti-gonococcus serum from a horse agglutinated gonococci and meningococci equally in a dilution of 1 in 2000, but in the opinion of Vannod (1906), Torrey (1907) and Elser and Huntoon (1909), who have studied this in great detail, agglutination tests serve to differentiate the three great groups from one another, provided that one uses active sera, that the results are properly controlled (the gonococcus is particularly susceptible to normal rabbit and group agglutinins), and that the strains chosen are not highly inagglutinable.

Complement deviation.-Wollstein (1907) obtained no difference between gonococci and meningococci by this method, but Teague and Torrey (1907) and Vannod (1906) have, on the other hand, found it to be of service in differentiating them, and I can confirm this latter opinion. The following figures, which are typical of many experiments made with anti-sera derived from rabbits which had been immunised over a long period with (dead and, later, living) cultures, illustrate the point. They were obtained from a simultaneously estimated series.

The method used was essentially that described in detail in the Journal of Hygiene, 1906, vol. vi. p. 267.

Constant amounts of organism emulsion and anti-serum were used and varying amounts of guinea-pig complement. This appears to me to be a much better method than that employed by Teague and Torrey, who kept emulsion and complement constant and varied immune-body. As the rabbits had been injected with cultures grown on human serum-smeared tubes, the emulsions for deviation purposes could not be used from cultures grown on these. The meningococei were therefore grown on agar and the gonococci on cat serum agar. Emulsions of approximately equal density were nade in salt solution and heated to $80^{\circ} \mathrm{C}$. for fifteen minutes before use. A luxuriant 24-hour agar growth of the meningococcus was emulsified with 1 c.c. of salt solution and made the standard of density. The amounts used for the tests were 0.1 c.c. of emulsion and 0.05 of anti-serum. The volumes were made up to 0.5 c.c. with saline solution, and then guinea-pig serum was added in increasing amounts. The mixtures were incubated for an hour and a half before adding the test 1 c.c. of sensitised ox red blood corpuscles.

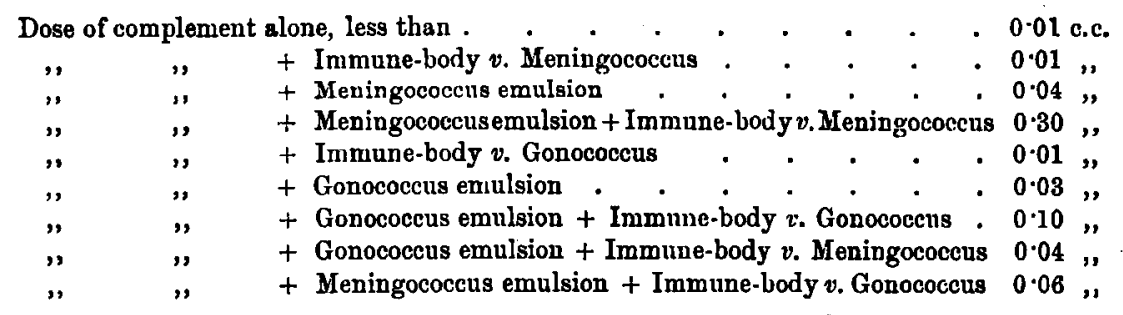

These results show that the immune sera alone do not appreciably 7—JL. OP PATH.-YOL. $x$. 
deviate; that the organism emulsions alone deviate four and three doses respectively; that the combination of organism emulsion plus the specific immune-body deviates thirty and ten doses respectively; and that the combination of organism emulsion plus non-specific immune-body deviates six and four doses respectively, thus indicating the presence of both specitic and group deviating immune-bodies in these anti-sera.

Similar results were obtained by the use of commercial antimeningococcic sera, Flexner's being more powerful than Ruppel's or that of Burroughs, Wellcome \& Co.

Bactericidal action. - The first account of the bactericidal action of serum on the meningococcus was published by Davis in 1907, but I had independently observed and studied the phenomenon with normal and meningitic patients' sera in the summer of 1907. The methods, the findings, and the results of their practical application to the treatment of cerebro-spinal fever by Dr. Ivy M'Kenzie and myself are given in detail in this Journal. ${ }^{1}$

Torrey in December 1908 published his results with rabbit sera, by which he had divided the gonococci into groups. I have since further studied the action of normal and immune sera obtained from rabbits on both the gonococcus and the meningococcus. ${ }^{2}$

The technique is difficult on account of the tendency of the gonococcus to undergo rapid autolysis in salt solution, to die even at room temperature, and to succumb to temperatures very slightly over $40^{\circ} \mathrm{C}$. The necessary precautions and controls make determinations very laborious. Comparative tests, to be of any value, must be simultaneously carried out, on account of the variations that occur in sera even of normal animals from day to day; so that it is practically impossible to compare a large series of strains by this method. Though Torrey is no doubt right in the main in holding that the gonococcus group is variable in this particular, as in agglutination and complement deviation reactions, the fact that he used different amounts of rabbit serum for activation with different strains and compared results on different days robs his results of much of their value.

The conclusions deduced from a large series of experiments are given below. They afford further evidence of important differences between gonococci and meningococci.

1. Normal sera may be bactericidal towards gonococci and meningococci. Of those tested (guinea-pig, rabbit, cat, human), cat's serum has proved most active on both organisms.

2. A normal serum may be distinctly bactericidal towards meningococci and yet have practically no effect on gonococci, e.g., guinea-pig and human sera.

3. The serum of a normal rabbit may vary within short periods of time, on one occasion being actively bactericidal towards meningo-

1 1908, vol. xii. pp. 539-548.

2 Proceedings of the Pathological Society of Great Britain, July 1909, p. 2. 
cocci, while on another almost without action. Simultaneous observations on gonococci showed comparatively little variation in the serum.

4. From rabbits inoculated with living cultures of gonococci and meningococci, bacteriolytic immune-bodies have been obtained which can be reactivated by feebly acting normal sera, a marked bactericidal action resulting. These immune-bodies are relatively specific; thus a reuctivated rabbit $v$. gonococcus serum which has a marked bactericidal effect on the gonococeus has only a slight effect on the meningococcus.

The following Tables show the results in more detail :-

At first experiments were tried with commercial anti-meningococcic sera, but as they contain on an average 0.4 per cent. of added phenol (for preservative purposes), which of itself is bactericidal, even in the presence of much albuminous matter (heated normal serum), true serum reactions were impossible.

The meningococcus emulsions were made with bouillon, 1 per cent. acid to phenolphthalein, 1 c.c. to an 18-hour serum-agar culture. 0.05 c.c. of a $1 \frac{1}{0}$ dilution was added to each tube. The volume was made up to 0.5 c.c. in each case by the addition of bouillon (not salt solution). After three hours' incubation 0.03 c.c. of each mixture was plated in 5 c.c.of a serum-agar mixture, and the results were read after two days' incubation. In the case of the gonococcus an 0.6 per cent. acid bouillon was used.

Effect of Phenol (0.4 per cent. aqueous solution) on Gonococcus and Meningococcus.

\begin{tabular}{|c|c|c|c|c|c|c|c|c|c|}
\hline 1 & \multicolumn{4}{|c|}{0.2 c.c. human serum ${ }^{I}+$ no phenol } & & • & 20,000 & \multicolumn{2}{|c|}{25,000 colonies. } \\
\hline 2 & " & " & +0.025 & c. $\mathrm{r}$ & sol & & less & 4,000 & " \\
\hline 3 & " & $"$ & +0.05 & " & " & . & ", & 1,200 & ," \\
\hline 4 & " & ", & +0.01 & ", & $"$ & . & " & 600 & ", \\
\hline 5 & ", & $"$ & +0.02 & $"$ & $"$ & . & 2000 & 2 & " \\
\hline 6 & , & ,. & +0.03 & ", & ", & . & 300 & 1 & ", \\
\hline
\end{tabular}

In a similar experiment these strengths of phenol had, even in plain bouillon, less action on either B. typhosus or V. Metchnikoff.

Effect of Guinea-pig's Serum on Gonococcus and Meningococcus.

\begin{tabular}{|c|c|c|c|c|c|c|c|}
\hline 1 & 0.3 c.c. & ea- & erum & . & & & onies. \\
\hline 2 & 0.15, & ", & ", & - & $\begin{array}{c}\text { practically } \\
\text { equal }\end{array}$ & 1 & $"$ \\
\hline 3 & $0.05 \quad 1$ & $"$ & $"$ & - & $\begin{array}{c}\text { about } \\
1000 \text { in each }\end{array}$ & 800 & $" 1$ \\
\hline 4 & 0.025, & , & ", & - & & 8,000 & ", \\
\hline 5 & Control, & erur & • & . & $\mathbf{5 0}$ & 2,000 & $"$ \\
\hline 6 & \multicolumn{4}{|c|}{ Control, $+0.1 \mathrm{c} \mathrm{c}$. heated human serum } & 1000 & 16,000 & ," \\
\hline
\end{tabular}

I This serum was of course inactivated by previous hesting to $57^{\circ} \mathrm{C}$. 
The gonococcus emulsion when plated at once gave a thousand colonies; when allowed to stand at room temperature, six hundred colonies; and when incubated, fifty only.

This illustrates the difficulties which have to be overcome in such experiments. The influence of even small proportions of heated serum on growth is also demonstrated.

Effect of Cat's Serum on Gonococcus and Meningococcus.

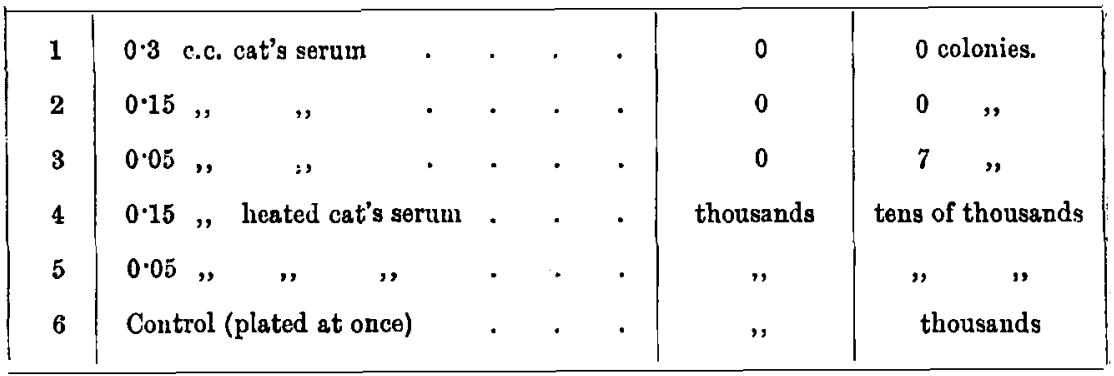

This cat serum was particularly active. Note also the different rates of growth of the two organisms.

Effect of Human Serum on Gonococcus, Meningococeus, and Bacillus typhosus.

\begin{tabular}{|c|c|c|c|c|c|c|c|c|c|c|}
\hline 1 & 0.3 & c.c & $m$ & erum & " & . & 1000 & 800 & \multicolumn{2}{|c|}{0 colonies. } \\
\hline 2 & 0.15 & , & " & ", & - & - & 1000 & 2500 & numerous & ", \\
\hline 3 & 0.05 & "' & $"$ & " & - & . & 1000 & 5000 & countless & " \\
\hline 4 & 0.3 & ", & ", & ", & (heated) & - & 4000 & 5000 & ", & " \\
\hline
\end{tabular}

This indicates woll how much sharper bactericidal action is in the case of the $B$. typhosus, all the organisms being killed off with the highest proportion of serum. It also shows how a serum may be actively bactericidal towards one organism and not to others. Whether this is an indication of multiplicity of bacteriophilic complements or of the presence of natural immune-bodies for some bacteria and not for others, is at present undetermined. (In this connection see Muir and Browning, 1908.)

So far illustrations have been given of the action of normal sera; in the following Table some typical results obtained with immune rabbit sera are set out. They were from a series simultaneously carried out. The same normal rabbit serum was used for both organisms. The immune sera were used both fresh and after they liad been heated (to $57^{\circ} \mathrm{C}$. for one and a half hours); this degree of heating destroys any complement but leaves any immune-bodies they may contain.

First observe the numbers in the control Plates 24 and 25 ; the gonococci have shown a slight tendency to die out in simple bouillon, but the meningococci have doubled their numbers within the incubation period of three hours. 
Effect of Normal, Immune and Reactivated Immune Sera from the Rabbit upon Gonococci and Meningococci.

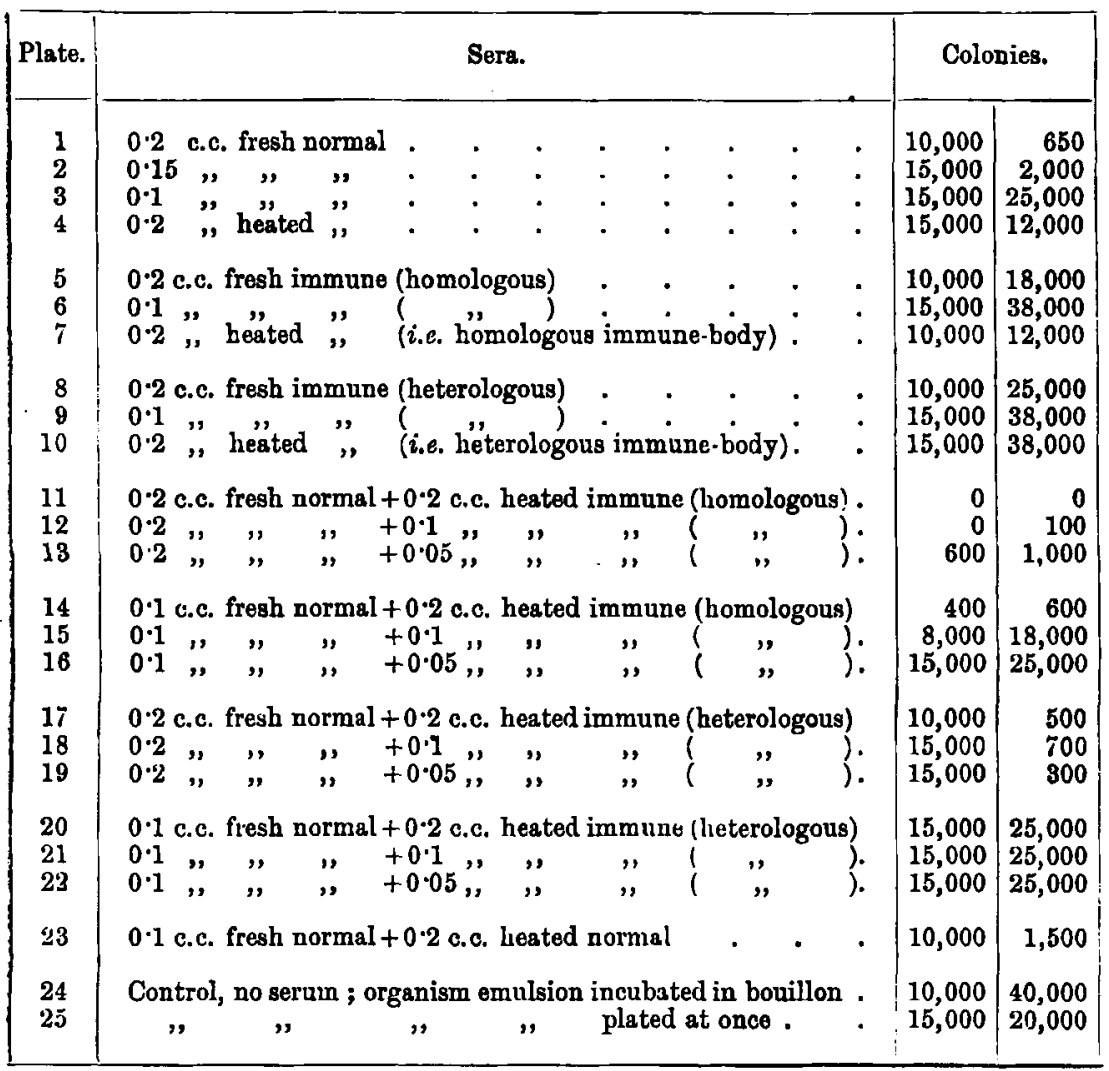

Here observe the action of the fresh sera-plates $1,2,3 ; 5,6 ; 8,9$. On the gonococcus, even the immune serum has little action. With the meningococcus, on the other hand, fresh sera have more action: the normul serum is mole potent than the inmune. As complement is supposed to vary with the health of the animals, it would appear that the long process of immunisation of these animals had weakened their natural complement, although the general condition and weights of both remained good.

Consider next the action after heating the sera-plates 4, 7, 10 ; the bactericidal action of fresh serum is in great part destroyed, but it will be observed (plates 1 and 4) that large amounts of heated serum still possess some bactericidal property. The theory of this is unknown.

The effect of combining fresh and heated normal serum is seen by comparing plates 3, 4 and 23. There is some enhancement of the action, particularly in the case of the meningococcus (second column figures).

A much more enhanced effect is, however, obtained by combining heated inmune serum with fresh serum-compare plates $1,7,11,12,13$, and 3, $7,14,15,16$.

Then, if the plates $11,12,13$, and $14,15,16$, be compared with $17,18,19$, and $20,21,22$ respectively, it will be seen that a heterologous heated immune serum, while it has some action, is not nearly so powerful as the homologous heated immune serum. 
Put in other words, we have here evidence of bactericidal immune-bodies in the sera of the immunised animals, which can be activated by complement (present in normal serum). These immune-bodies are also relatively specific.

The above bactericidal results all indicate the importance of complemented immune sera for the destruction of these organisms. Now, while the immunity to any infection must be a very complex thing, and lies far deeper than in mere alterations of a few observed properties of serum or leucocytes, still it would appear reasonable to employ such sera in the treatment of gonococcal and meningococcal infections. Intra-spinally injected, specific immune sera have already considerably reduced the mortality in cerebro-spinal fever, but if a highly immune polyvalent serum were suitably complemented the results might be even better. In the case of gonococcal infections the necessity is even greater for a specific immune serum. How this can best be attained in practice, whether by active immunity (vaccines) or by passive immunity (polyvalent sera from animals), must be left to the future to decide. As even now there is a considerable body of evidence to show that organisms can acquire a high degree of resistance to antagonistic substances of all kinds when they are subjected to such influences gradually over a period, chronic infections must be more difficult to eradicate than recent ones. Here it would appear that if, for example, vaccine therapy is to be carried out, the strain which is used will be of importance.

\section{General Conclusion.}

The evidence adduced in the foregoing pages all goes to show that the terms Gonococcus, Meningococcus, and Micrococcus catarrhalis not only stand for fairly definite pathogenic entities, but that they are representative of types of organisms which, though closely similar, can be differentiated by a summation of characters observed in a study of their conditions of growth, cultural appearances, fermentative properties and serum reactions. So that given, from a human source, a Gram-negative organism of appropriate morphology, it is possible to identify it by bacteriological laboratory methods. As has been shown, the vast majority of these pathogenic Gram-negative organisms conform to fairly distinct types, although within each type considerable variations occur. Occasional variants are, however, met with which deviate further from the mean than usual, and to which there is difficulty in allocating definite names. The very existence of these borderland organisms invalidates, in the eyes of some, the claim of the above types to specific rank, and hence to distinctive names; but in the present state of knowledge, until systematists are more agreed as to what exactly constitutes a species, it is a great practical convenience to retain the names, more particularly as borderland organisms are only very rarely encountered in practice. 
I have pleasure in acknowledging my indebtedness to Professor Muir for his kindly interest in, and friendly criticism of, the work at various stages.

\section{REFERENCES.}

Andrews, F. W. . . . "A Case of Acute Meningococcal Septicæmia," Lancet, London, 1906, vol. i. p. 1172.

ARkwright, J. A. . . . "Varieties of the Meningococcus with Special Reference to a Comparison of Strains from Epidemic and Sporadic Sources," Journ. Hyg., Cambridge, 1909, vol. ix. p. 104.

Brovs, C. . . . . . . "Beitr. z. Frage der gram-negativen Diplokokken der Bindehaut," Klin. Monatsbl. f. Augenh., Stuttgart, 1907, Bd. xlv. S. 1.

Bruckner, J., et C. Chris- "Agglutination du gonocoque par un sérum TŔANU spécifique," and other papers, in Compt. rend. Soc. de biol., Paris, 1906, tome lx. p. 846, etc.

Buchanan, R. M. . . . "On the Differentiation of the Meningococcus from other Gram-negative Diplococci in the Naso-pharynx of Cerebro-spinal Fever Contacts," Lancet, London, 1907, vol. i. p. 1590.

Bom, E. . . . . . . "Menschliches Blutserum als Nährboden für pathogene Mikro-organismen," Deutsche med. Wchnschr., Leipzig, 1885, No. 53, S. 910.

Chester, F. D. . . . . "A Manual of Determinative Bacteriology," London, 1901, p. 27.

Davis, D. J. . . . . . "Studies in Meningococcus Infections," Journ. Infect. Diseases, Chicago, 1907, vol. iv. p. 558.

DuNHAM, E. K. . . . . "Comparative Studies of Diplococci decolorised by Gram's Method, obtained from the Spinal Fluid and from the Nares of Cases of Epidemic Cerebro-spinal Meningitis," Journ. Infect. Diseases, Chicago, 1906, Suppl. No. 2, p. 10.

Dunv, R. A., AND M. "Remarks on the Clinical and Bacteriological H. Gordor Aspects of an Epidemic simulating Influenza,"

Elser, W. J., and F. M. "Studies on Meningitis," Journ. Med. Research, HUNTOON

Boston, 1909, vol. xx. p. 402.

Escr, P. . . . . . . "Ein Beitr. z. Ziichtung des Meningococcus," Centralbl. f. Bahteriol. u. Parasitenk., Jena, 1909, Abth. 1, Orig. Bd. lii. S. 150.

Finger, Ghon, und "Beitr. z. Biol. des Gonococcus," Arch. f. Schlagenhaufer $\quad$ Dermat. $u$. Syph., Wien, 1894, Bd. xxviii. S. 3. FishrR, J. W. . . . . "A Study of Agglutination," Journ. Med. Research, Boston, 1907, vol. xvi. p. 203.

Flexner, S. . . . . . "Contributions to the Biology of Diplococcus intracellularis," Journ. Exper. Med., Baltimore, 1907, vol. ix. p. 105.

Goodwis, M. E., AND A. I. "The Frequent Occurrence of Meningococci in voN Sholly the Nasal Cavities of Meningitis Patients and of those in direct contact with them," Journ. Infect. Diseases, Chicago, 1906, Suppl. No. 2, p. 21 .

Gordon . . . . . See Dunn and Gordon, 1905. 
GuRd, F. B. . . . . . "A Contribution to the Bacteriology of the Female Genital Tract, with Special Reference to the Detection of the Gonococcus," Journ. Med. Research, Boston, 1908, vol. xviii. p. 291.

Henderson, L. J. . . . "Concerning the Neutrality of Protoplasm," Proc. Soc. Exper. Biol. and Med., New York, 1906-7, vol. iv. p. 87 (abstract).

Henderson, L. J., and H. "The Preservation of Neutrality in Culture B. W hBster

Hiss, P. H., AND H. "A Report of Twenty-four Cases of Epidemic
Zinsere

Ziss, P. H., AND H. "A Report of Twenty-four Cases of Epidemic
Meningitis treated with Leucocyte Extract," Media with the Aid of Phosphates," Journ. Med. Research, Boston, 1907, vol, xvi. p. 1. Journ. Med. Research, Boston, 1908, vol. xix. p. 429.

Hodston, T., axd J. C. "The Opsonic and Agglutinative Power of RANKIN

Blood Serum in Cerebro-spinal Fever," Brit. Med. Journ., London, 1907, vol. ii. p. 1414.

KuTscerr, K. H. . . . Kulle und Wassermann's "Handbuch der pathogenen Mikro-organismen," Jena, 1907, Erster Ergänzungsband, S. 494.

von Lingelsherm, W. . . “Die bakteriologischen Arbeiten der Kgl. Hygienischen Station zu Beuthen O.-Schl. während der Genickstarreepidemie in Oberschlesien im Winter 1904-1905," Klin. Jahrb., 1906, Bd. xv. S. 373.

MACGREgor, A. S. M. . . "Cerebro-spinal Meningitis-Immunity Phenomena with Reference to Clinical Aspect," Brit Med. Journ., London, 1908, vol. ii. p. 1343.

Mallory, F. B., and J. H. " Pathological Technique," Philadelphia, 1904, WRIGHT

M'Kenzie I., and W. B. "Serum-therapy in Cerebro-spinal Fever," M. Martin

MoORE, B.. . . . . . Murr, R., AND W. B. M. "On the Deviation of Complement by a Serum
MaRTIN MaRTin Journ. Path. and Bacteriol., Cambridge, 1908, April, vol. xii. p. 539.

"The Fquilibrium of Colloid and Crystalloid in Living Cells," in L, Hill's "Further Advances in Physiology," London, 1909, p. 21 et seq. Precipitin Test," Journ. Hyg., Cambridge, 1906, vol. vi. p. 265 .

Nersser . . . . . Verhandl. der deutsch. dermat. Gesellsch., 1899, S. 133.

Neisser, A., axd W. "Gonorrhoe," in Kolle u. Wassermann's " HandSCHOLTZ buch der pathogenen Mikro-organismen," Jena, 1903, Bd. iii. S. 148.

NoGUCHI, H. . . . . "On the Influence of the Reaction and of Desiccation upon Opsonins," Journ. Exper. Med., Baltimore, 1907, vol. ix.

Rrvas, D. . . . . . . "An Improved and Rapid Test for Indol in Broth Cultures, and for the Presence of this Substance in Meat Sugar-free Broth," Joum.

RoTHE: Infect. Diseases, Chicago, 1907, vol. iv. p. 641.

"Ueber die Verwendung verschiedener Zuckernährboden zur Differentialdiagnose der Gonokokken," Centralbl. f. Bakteriol. u. Parasitenk., Jena, 1908, Abth. 1, Orig. Bd. xlvi. S. 645. 
Shensan, T., and W. T. "A Bacteriological Investigation of Epidemic Ritchie

Storvesand, K. . . . " E. 456 . 45 . Untersuch. meningitisverdächtigen Materials," Centralbl. f. Bakteriol. u. Parasitenk., Jena, 1908, Abth. 1, Orig. Bd. xlvi. S. 295.

Strong, R. P. . . . . "Protective Inoculation against Plague," Journ. Med. Research, Boston, 1908, vol. xviii. p. 325.

STross, O. . . . . . "Ueber das Wachstum der Gonokokken auf serumbaltigen Nährboden," Centralbl. $f$. Bakteriol. u. Parasitenk., Jena, 1905, Abth. 1, Orig. Bd. xxxviii. S. 491.

Symmers W. ST. C., ANJ) W. J. WILSON

"Some Points bearing on the Bacteriology of Cerebro-spinal Meningitis," Journ. Hyg., Cambridge, 1909, vol. ix. p. 9.

ThalmanN . . . . "Züchtung der Gonokokken auf einfachen Nährboden," Centralbl. f. Bakteriol. u. Parasitenk., Jena, 1900, Abth. 1, Bd. xxvii. S. 828.

Trague, O., and J. C. - "A Study of Gonococcus by the Method of TORREY

Torrer, J. C. . . . . "Agglutinins and Precipitins in Anti-Gonococcic Fixation of Complement," Journ. Med. Research, Boston, 1907, vol. xvii. p. 223.

Torker, J. C. . . . . "Agglutinins and Precipitins in Anti-Gon
Serum," ithid., 1907, vol. xvi. p. 329.

"Bacteriolysis of the Gonococcus and of the Meningococcus, with Normal and Specific Immune Rabbit Serums," itid., 1908, vol. xix. p. 471.

Trautmand, H. and W. "Beitr. z. Epidemiologie und Bakteriol. der FroMME epidemischen Genickstarre," München. med. Wehnschr., 1908, S. 791.

VANvod, TH. . . . . . "L'agar ordinaire, comme milieu de cultur du gonocoque," Centrallbl. f. Bakteriol. u. Parasitenk., Jena, 1905, Abth. 1, Orig. Bd. xl. S. 162.

"Contributions à l' étude du gonocoque," ibid., 1907, Abth. 1, Orig. Bd. xliv. S. 10.

Wassermans, A. . . . "Ueber Gonokokken-cultur und Gonokokkengifte," Berl. klin. Wchnschr., 1897, No. xxxii. S. 685.

WATABIKI, T. . . . . "The Behaviuur of the Gonococcus in Carbohydrate Media," Journ. Med. Research, Boston, 1909 , vol. xx. p. 365.

Wertheim . . . . "Reinzuichtung des Gonococcus Neisser mittels des Plattenverfahrens," Deutsche " med. Wchnschr., 1891, Bd. xvii. S. 1351.

Wildboiz, H. . . . . "Zur Biologie der Gonokokken," Centralbl. $f$. Bakteriol. u. Parasitenk., Jena, 1902, Abth. 1, Orig. Bd. xxxi. S. 128.

" Bakteriologische Studien über Gonococcus Neisser," Arch. f. Dermat. u. Syph., Wien, 1903, Bd. lxiv. S. 225.

Wollstein. M. . . . . "Biological Relationships of Diplococcus intracellularis and Gonococcus," Journ. Hixper. Mfed., Baltimore, 1907, vol. ix. p. 588. 


\section{DESCRIPTION OF PLATES XV.-XVIII.}

\section{Plate XV.}

FiG. 1.-Gonococcus (K.S.), stroke culture, 1 day's growth. Note the extreme transparency of the growth. ( $\times 9$ diameter.)

Fio. 2.-Gonococeus (S.), stroke culture, 5 days' growth. The semi-confluent nature of the growth and supergrowth granules are shown. ( $\times 9$ diameter.)

Fic. 3. -Gonococcus (0.N.), 3 days' growth. Note the granularity of the centre. There is slight radial striation, but the margin is comparatively circular. $(\times 9$ diameter.)

Fic. 4.-Gonococcus (W.), 3 days' growth. Note the granular centre, the scalloped margin and the radial and concentric striation. ( $\times 9$ diameter.)

FiG. 5.-Gonococcus (K.C), 3 days' growth. Note the granular centre and the general plicated uature of the colony. ( $\times 9$ diameter.)

Fra. 6.-Gonococeus (C.), 3 days' growth. Note the granular centre and the extreme plication of the colons. ( $\times 8$ diameter.)

Fig. 7.-Gonococeus (H.), 5 days' growth. ( $\times 8$ diameter.)

Fig. 8.-Gonococcus (K.S.), 5 days' growth. Note the extreme degree of marginal scalloping. ( $\times 9$ diameter. $)$

FIG. 9.-Gonococeus (V.), 5 days' growth. A highly typical gonococcus picture is presented. Contrast with Fig. 10, which shows another colony of the same strain grown on the same plate. ( $x 9$ diameter.)

Frg. 10. Gonococcus (V.), 5 days' growth. To contrast with Fig. 9. There is much less differentiation, and the colony was more opaque as seen with the uakel eye. ( $\times 9$ diameter.)

\section{Plate XVI.}

Fio. 11.-Gonococcus (K.C.), 13 days' growth. The granular centre, the plication of the colony, the radial and concentric striations and the scalloped margin are all shcwn. Note commencing supergrowth granulations forming a zone where cuncentric striation is most marked. ( $\times 7 \frac{1}{2}$ dianeter.)

FIG. 12.-Gonococcus (K.C.), 13 days' growth. Contrast with Fig. 11. These colonies were grown on different plates. Here there is a greater degree of granularity in the centre, causing opacity, and supergrowth granulations are more marked, but concentric striation is less in evidence than in Fig. 11. ( $\times 7 \frac{1}{2}$ diameter. $)$

FIG. 13.-Gonococcus (C.), 10 days' growth. The granularity of the centre is limited. The dark circular shadow is due to a large supergrowth ont of focus. The plication of the colong has given the optical etfect of lily leaves. $(\times 7 \mathrm{t}$ diameter.)

\section{Plate XVII.}

Fig. 14.-Gonococcus colony appearances, drawn by Mr. A. K. Maxwell. A light and shade stereoscopic effect impossible with direct photography"is thus obtained.

(a) Gorococcus (K.C.), 2 days' growth.

(b)

(c)

(d) "

" 5 " $"$

, $12, "$,

(e) " (T.) 12 ,

", showing tendency of colonies to remain discrete.

(f) " $\quad$ (K.C.) 12 " " ", showing few but large supergrowths.

F1G. 15.-Gonococcus (K.C.), 6 days' growth. Nate comparative translucence of wholo colony. A series of supergrowths are forming a ring mid-way between margin and centre. (The dark central shadow is due to the inoculating point having cracked the surface of the medium.) $(\times 9$ diameter. $)$ 


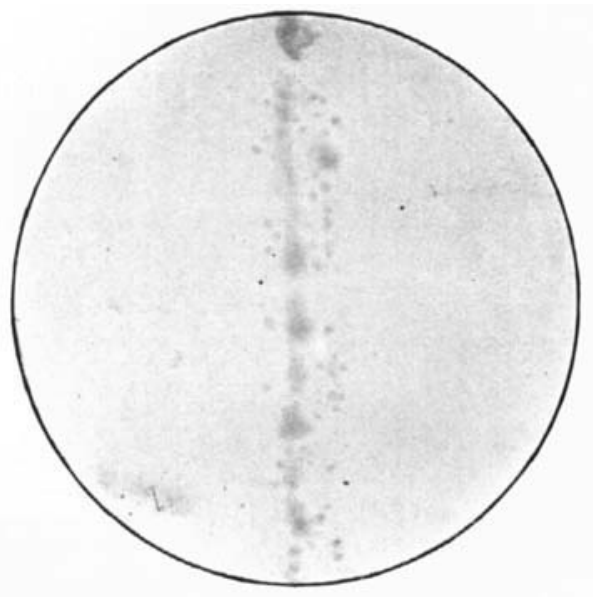

Fig. 1.

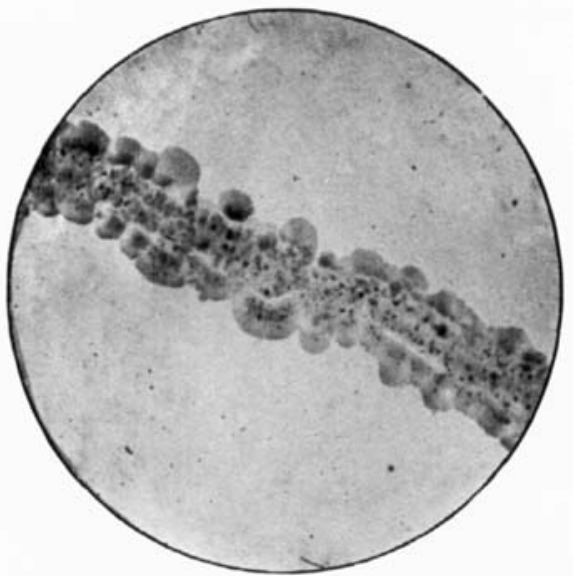

Fig. 2.

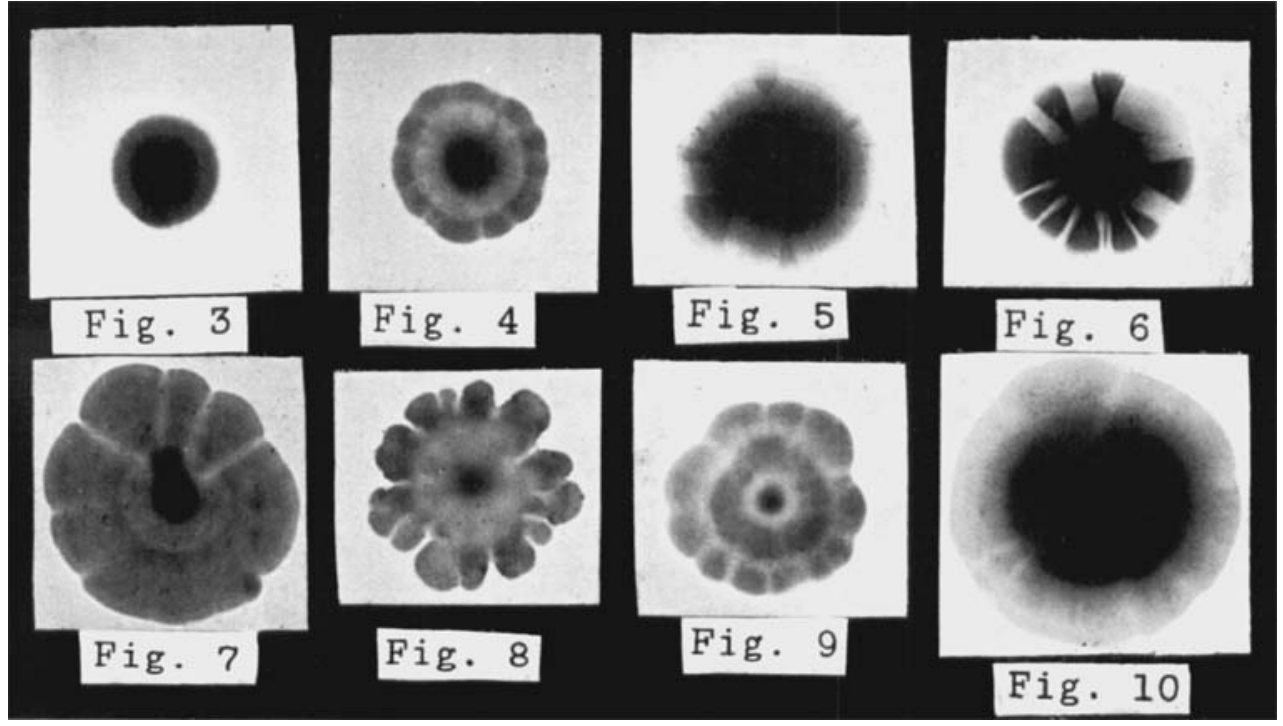




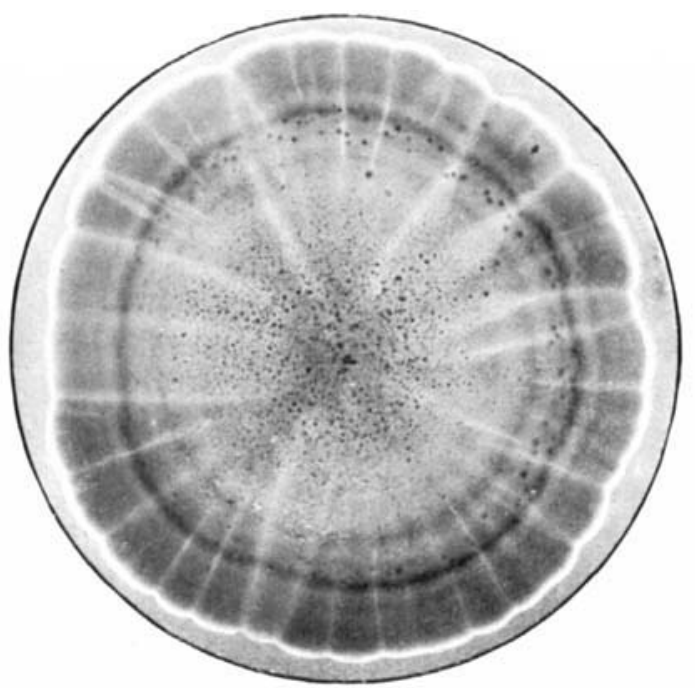

Fig. 11.

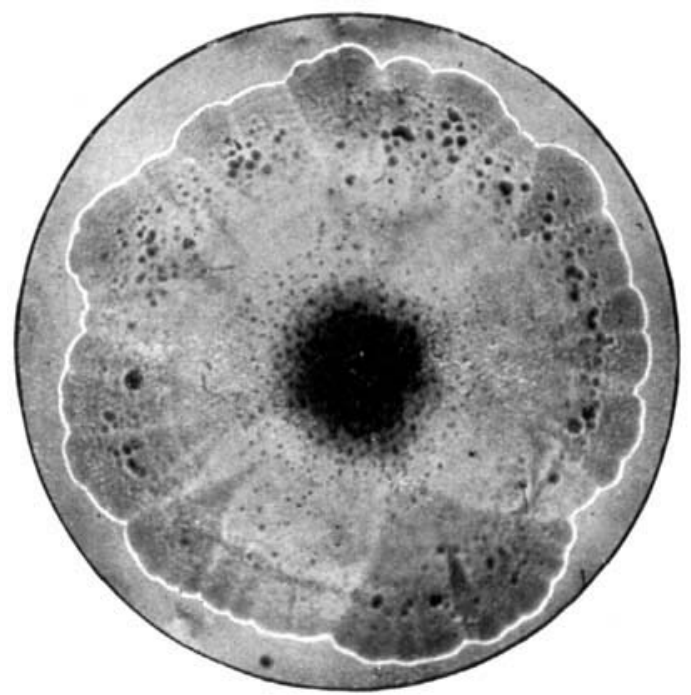

Fig. 12.

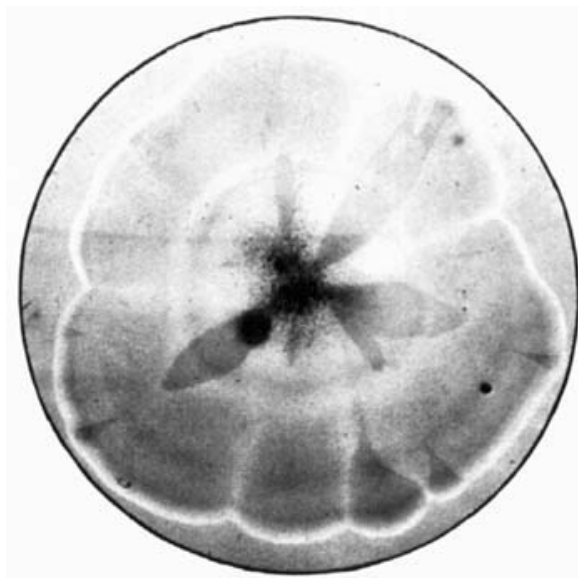

Hig. 13. 


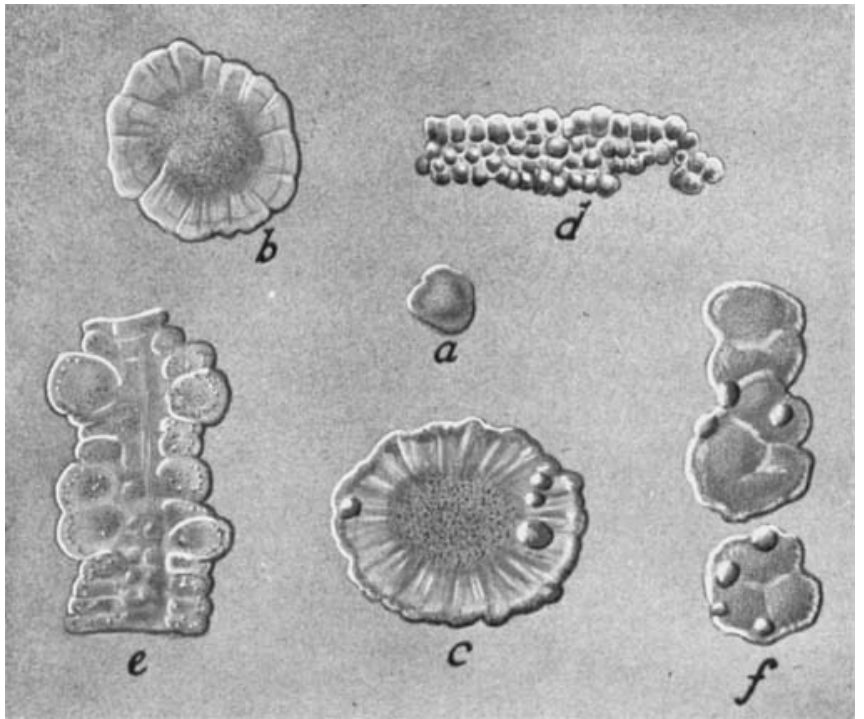

Fig. 14.

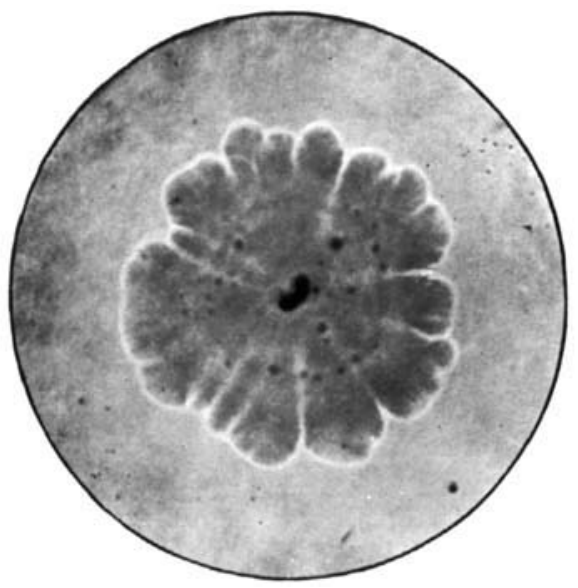

Eig. 15.

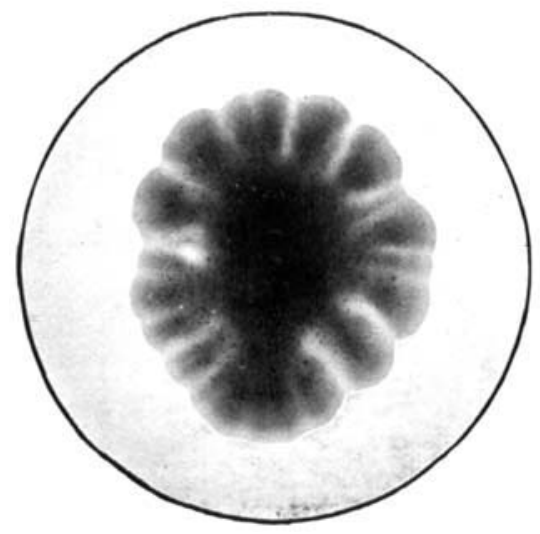

Fig. $1 \%$.

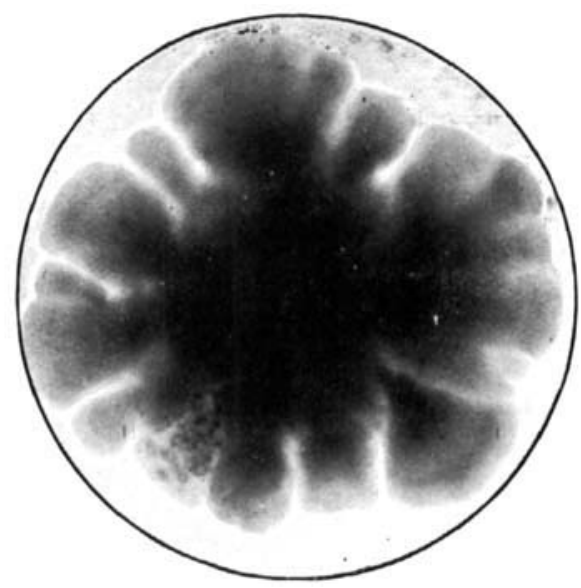

Fig. 16.

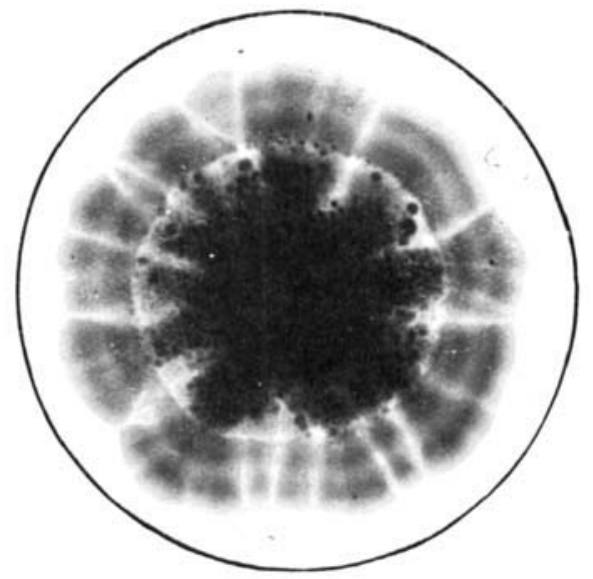

Fig. 18. 


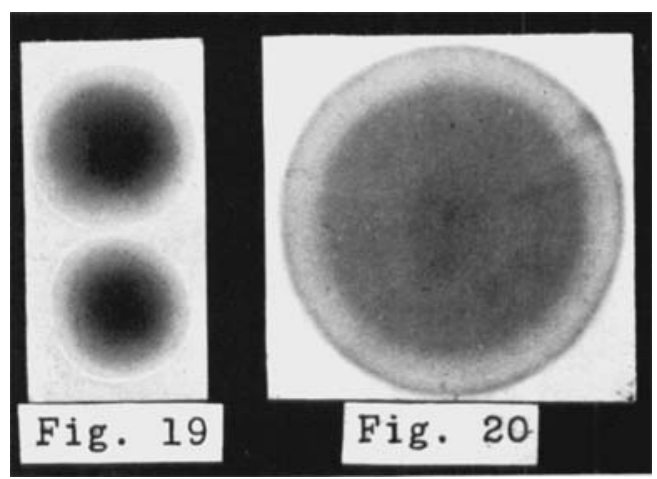

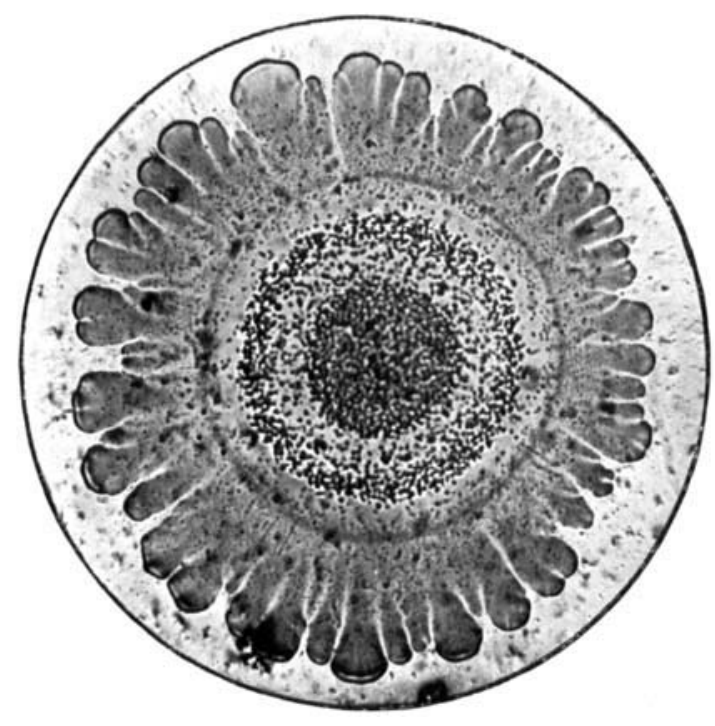

Fig. 21.

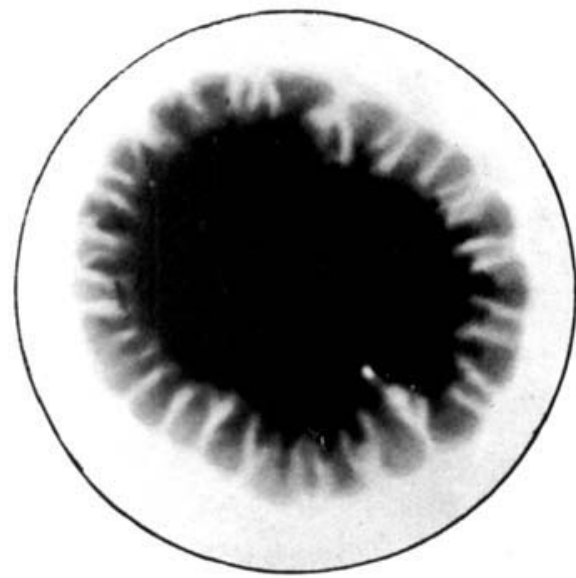

Fig. 2P.

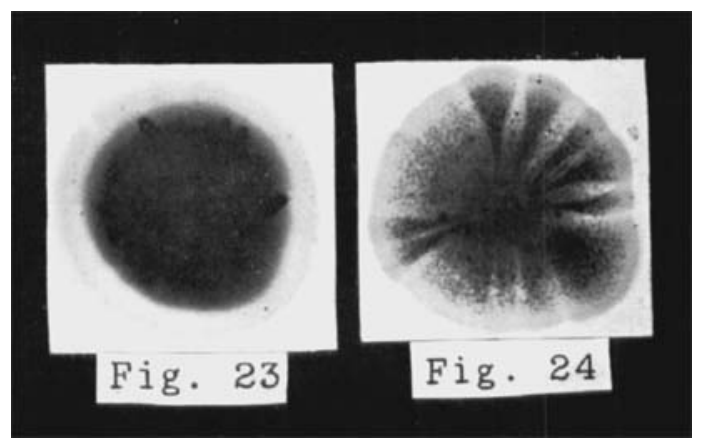


FrG. 16.-Gonococcus (K.S.), 10 days' growth. Naked eye this colony was rather opaque and without central granulation. Note, supergrowths have appeared at one place near the margin. ( $x 9$ diameter.)

Fig. 17.-Atypical arthritis organism (see page 93), 7 days' growth. Note extreme plication of the colony and its comparative opacity. Coarse granulations are visible on the surface. ( $\times 9$ diameter.)

Frg. 18.-Atypical arthritis organism, 13 days' growth. Note the well-marked coarse grannlation of the central portion. $\left(\times 7 \frac{1}{2}\right.$ diameter. $)$

\section{Plate XVIII.}

Frg. 19.-Meningococcus (S.), stroke culture, 2 days' growth. Note contrast between opaque centre and delicate transparent margin. ( $\times 9$ diameter.)

Fic. 20,-Meningococcus (L.F), 2 days' growth. The optical arrangements were specially altered to show the contrast between the moderately gramular centre and the transparent marginal zone ; the dark rim is an optical " artefact," consequent on the change. $(x 12$ diameter. $)$

Fra. 21.-Meningococcus (L.F), 8 days' growth. This rare appearance was produced by allowing the plate to partially dry (see page 87). The granular appearance in the centro is entirely due to crystalline deposits. Some small supergrowths are visible near the margin. ( $\times 7 \frac{7}{2}$ diameter.)

FIG. 22.-Micrococcus catarrialis, 7 days' growth. Note the extremely crenated margin and the very opaque centre. The colony is too opaque to photograph well by this method. ( $\times 9$ diameter.)

Fic. 23. - Catarrhalis-like organism of the Micrococcus pharyngis siccus type, 5 days' growth. The very dense central shadow gives no idea of the crinkled raised centre visible to the naked eye. ( $\times 9$ diameter.)

Fig. 24.-Catarrhalis-like organism, 5 days' growth. The appearance presented is a rare one. The resemblance to the gonococcus is more apparent than real. Naked eye, the colony was greenish yellow. This organism fermented lavulose and maltose. ( $\times 9$ diameter. $)$

The colonies were all grown on plates of the gonococcus inedium and were photographed by transmitted light. The letters in brackets indicate the strain of organism used. 